\title{
Draft for Understanding the Historical Background of Changes in the Ideological Language and Communication of Secret Services in 20th Century's Hungary
}

\author{
Bela Revesz ${ }^{1}$
}

Published online: 11 August 2020

(c) The Author(s) 2020

\begin{abstract}
Words can mean different things to different people. This can be problematic, mainly for those working together in a bureaucratic institution, such as the secret service. Shared, certified, explicit and codified definitions offer a counter to subjective, solitary and/or culturally dominant definitions. It's true that codified secrecy terms for secret services can be seen to involve a number of political, cultural, subcultural "languages", but if words come from unclassified or declassified files, memorandums and/or records, one needs a deep understanding of the secret services. A remarkable feature of this bureaucratic language is the evolving nature of, certain "keywords" as important signifiers of historical transformation. Thus, the changes in the language of the secret services depends at least as much on the internal changes of the secret services as on the transformation in the external political-social environment. In spite of the confusion of Hungarian secret services in the revolutions of 1918-1919 and the disintegration of the Austrian-Hungarian Monarchy, in the early 1920's became a stable system. Between the two World Wars, the Hungarian State Police directed by the Ministry of Internal Affairs (hereinafter referred to as MIA), the Military Intelligence and Counter-Espionage directed by the Ministry of Defence (hereinafter referred to as MoD), and the Hungarian Royal Gendarmerie directed by both of the Ministries had their own operational service. This structure existed unchanged until 1945. Simultaneously with the forward advance of the soviet troops, government began to re-establish the former system of the secret services in the eastern part of the country. After WWII, in 1946, the "State-protection Department" as political police became independent from the police. However, from the beginning, they remained under the control of the Communist Party. After 1950, the State Security Authority provided special services for the MIA and the Military Political Directorate of the MoD. After quashing the revolution in 1956, in the spring of 1957, the MIA Political Investigation Department was established which — with slight modifications - kept the structure created during the "state protection era". The MIA III. The State-Protection General Directorate was established
\end{abstract}

Extended author information available on the last page of the article 
in 1962. The reorganization was finalized in the middle of the 1960's, which resulted in the new system, which-with the structure of Directorates-became the ultimate structure of the state secret police until the abolishment of the MIA General Directorate III in January 1990. These organizational transformations were largely the result of exogenous historical-political changes. Moreover, each new period had a major impact on the organizational communication, language use and vocabulary of the secret services. This study seeks to interpret these historical transformations.

Keywords Secret Services · Communication - Bureaucratic changes · Socio-Political transformations $\cdot$ Hungarian Soviet Republic $\cdot$ Horthy Era $\cdot$ One-Party System

\section{Introduction}

Ludwig Wittgenstein, the founder of the modern philosophy of language, in one of his earlier dissertations [105: 230-235] saw the only, perfectly meaningful use of language as a complete representation of facts. He also stated that any attempt to use it in any other way is necessarily meaningless. In later works [107: 280], in his preliminary thoughts Wittgenstein already expressed his doubts about the role of language as it described the world exclusively, and rather regarded it as a set in which all activities serve a different purpose than the description of the world and it has rather an "imaging" function. In fact, this latter function has been given priority in Philosophical Investigations [106: X]: "Philosophy simply puts everything before us, and neither explains nor deduces anything. -Since everything lies open to view there is nothing to explain." Slightly at odds with the decisive logical interpretation over the years, is that not only the everyday "social" language has come to the forefront, but also the emphasis on the fact that in the linguistic structure, the linguistic sign and the object/subject of the language are only conditionally linked. This recognition was leaning towards that which was identified in later research in conjunction with anthropological linguistics. The discipline of sociolinguistics focuses especially on social factors, which sets out that different forms of speech can be linked to different groups and social strata. As such, language is a set of dialects and styles formed along different variants, territorial and social indicators. Taking this interpretation, the heterogeneous language set of the community as a whole, and its variations have already drifted from the original language concept of Wittgenstein. His theory is firmly aimed toward the language, as the complete representation of facts. The more general effects of the change in the mind-set of the philosophy of the language described above were experienced in the second half of the 20th century. [74: 595] During this period, which also can be considered as the emergence of sociolinguistics, the representatives of the discipline started focusing on examining the links between language use and society in linguistics around the world. The methodology of this study will use the latter version, when Wittgenstein intended to acknowledge a connotative viewpoint.

In addition to the functions in the process of thinking and exploration of reality, the most basic form of social interaction, language also plays an emotional 
and expressive role The sociological, socio-psychological aspect of this phenomenon is how the complexity of social structures are reflected in the social structure of the language, and whether the different subcultures are expressed in the diversity of linguistic identities. [9: 21] If we denote the essence of communication at all times in the communication and exchange of information, even in the digital world of the information society, the most appropriate instrument for this is the written and/or spoken signal system, the language. The extensiveness, validity and generality of this instrument depends primarily on the breadth of the social set that needs to communicate and exchange information in the collective action of the society to optimize their interactions. The need for co-operation is the most important integrating factor for community existence and survival. The community's basic need, therefore, is the identical and unequivocal correspondence between the language marking and the phenomenon indicated. If this community is organized by the state power, it will usually interact with each other in the form of the language of the state power and the public language used by citizens. According to some approaches, this pattern is determined by the more demanding linguistic interactions of higher-educated, more cultured people; which can be also defined as the normative language version of the linguistic area. [29: 431-42]

In contrast to this "linguistic standard", the sociolinguistic approach defining the concept of public language, which eliminates the role of these value factors from this definition and considers the public language as "everyone's" or "people's" communication instrument. However, both approaches are generally common in accepting that another special sublanguage also serves to communicate between the groups on the lower levels of the general population. The peculiarity of the sublanguage is that it is a less-written, more spoken, micro community-specialized language, and it is markedly different from the dialects by region, which can be called regionalpublic languages. In this respect, the structure of society, which is first defined by aggregation of individual statistical characteristics (age, education, income, place of residence, etc.), may also be suitable for describing levels of linguistic structure. Collective criteria, such as the relation of certain social groups to power and inequality, add another dimension to the demonstration of the connections between the two systems. As a result, it can be examined, for example, why users of certain languages or their variants have no social influence or are excluded, while a group speaking another language or variant exercises social, economic or political power. [88: 3-17] In multilingual communities therefore, it is also possible to study the real and symbolic role that each language plays in the life of the examined community and it is also possible to easier understand, how a language variant and social identity are related, or why is it possible, that one minority is able to preserve its language over a long period of time, while another replaces significantly its old linguistically elements to new ones over a few generations

From the beginning of the 19th century, in Europe, all professional speaking communities demanded the use of independent terminology as a typical set of specific 
technical terms for particular purposes linked to the specific speech situations of the profession. ${ }^{1}$

As a part of the idea of nationalism, the monopoly of the universal Latin language in the disciplines has been strongly overshadowed by the rise of the national language, but owing to the basic methods of the creation process of terminology - revive already forgotten words, new vocabulary and mirror translations - some elements of the traditional Latin vocabulary also survived in the emerging new terminologies. More or less the same process had taken place in Central Europe, where the German (and Italian) language elements had the greatest impact on terminological changes. [89: 31]

From the extensive literature on terminology, the following cited statement of almost a hundred years ago may be recalled for its lasting validity and accuracy to this day: "The accessories of artificial word or technical term, are therefore conceptual accuracy, linguistic correctness, purity, furthermore the ease of application and consistency; these are accompanied even by a negative requirement: they should not have an emotional side-tone or mood accompanying words, like the terms of literary, conversational and any other public language terms, as they could obscure their specificity. From an aesthetic point of view, it is enough if it is not complicated and easy to pronounce. Its beauty should be like a machine part, which is consummate if it is perfectly suited to its aim and purpose." [95: 78]

\section{Research Methods and Materials}

Unlike the so-called "civilian" terminologies, the terminology of the secret services has the specialty that the secret services themselves differ from other state and nonstate actors, which is their "unknowability", their confidentiality. The way to understand the linguistic secrecy of the secret services may be through the interpretation of the concept of secrecy.

The secret services (state protection, state security, national defence, national security bodies, intelligence, counter-intelligence, political police, etc.) had been created as part of the prevailing socio-power structures. Since their creation, they have been in continuous operation, under non-public (internal) regulations, within a secret institutional framework, clandestine staff and the use of special covert techniques to protect the different types of sovereign state powers. The lack of information had always been created largely in the dictatorships and to a lesser extent in democracies as a "mysterious image" to the clandestine activities of these services. The pursuit of constant hiding from the "enemy" unfortunately also hides the information from "friendly" views, and therefore the most important structured system of human cognition, the science itself, is also restrained from being able to fully gather and analyse the information concerning the secret services.

\footnotetext{
1 Just a few examples to illustrate how different disciplines focusing on the history of their own language of specialty and their peculiarities: $[20,22,25,28,29,33,45,47,49,50,76,80,82,89,96,99]$.
} 
Strangely enough, in order for this particular research object to be conceived of as verifiable knowledge by rational reasoning, there must also be suitable political conditions. Namely, the secrets of the secret service structures mostly appear in the exchange of power leaders/leaders, but not infrequently during the change of political elites, regimes, systems, at least to the extent and in the manner deemed useful by the leadership of the new power. In such periods, large revelations may approach objective (half-)truths, however withholding information or their "leak" can also erode the critical independence and autonomy of scientific knowledge. These are the reasons, why the "boosts" in the research of secret services are mostly linked to major political and social "shocks", when the new political regime seeks to use the legitimacy of science to criticize the former political leadership or to validate its own power. Moreover, the most appropriate means of doing so is to fully disclose the evil, immoral, corrupt, cruel, and cynical features of the former leadership. The revelations are "delighted" to be joined by a part of the public, which, by virtue of its anti-politicization attitude, considers all power manoeuvers to be immoral, and furthermore the science, for which it is important that so-called but hidden political information is suddenly revealed can be processed by scientific means. It is no coincidence, therefore, that the research field of the secret services is dominated by social, institutional, and political history, and is relatively marginalized by other scientific research areas.

The use of the term "secret service" also requires preliminary explanation. Spies, Secret Agents, Operatives, Intelligencers, Exploratories, Reconnaissants, Counterintelligence officers, Undercover informers, Clandestine Staff, Confidants, Network Members, etc. The institutions that provide the framework for its activities appear in a variety of common and frequently used names in the public and press languages, and sometimes in the specialized literature. Part of the distinction is due to differences in substance. In many cases, however, it is only their conceptual ambiguity that makes these terms meaningful. At the same time, under the term secret services irrespective of the era and political-power context, all forms of hidden information gathering and/or counterintelligence activities, which have the basic purpose of maintain the prevailing state sovereignty can be considered collectively. Thus, it does not take into account the degree of institutionalization of the forces engaged in these activities, the form, directions of their activities, nor the legitimacy basis of the given state power-while being bound to the state is an indispensable condition. It is also true that the protection of sovereignty, more or less directly, is dealt with by all governmental bodies, but of these, the use of special, covert, secret, operative forms, methods, forces and means is solely the attribute of the secret services.

"When we get to know a secret (...), first of all we feel special, which initially feels good. Then knowledge becomes more and more a burden and some become anxious that they cannot tell this secret to others. The reality is that, we really want to reveal it, but at the same time, they also know that it would violate their confidence in them. At first glance, one might think that there is no simpler, more childlike thing than secrecy, but then it turns out that they are 
actually working on very complex processes."2 Philip Zimbardo, the professor of psychology at Stanford University, interprets the essence of the secret as the cognizant of the secret, which phenomenon had also been approached in the Gospel of Luke from the direction of dynamics: "For there is nothing hidden that will not be made manifest, nor secret, that will not become clearly known, and come into illumination.". The two types of vision can already well illustrate that the secret phenomenon is based on at least two pillars, at first glance; its subject and material aspects can be distinguished. How this can be linked to a well-defined occupation, in this case a particular group of secret services can be easily read from this duality. The most diligent "secret factory" is the secret service of the prevailing state in which, according to historical examples, not only the "hero" or "victim", but also the actors of everyday life can easily develop some kind of hidden relationships. On the other hand, as the Bible states: these secrets are not eternal, with time they will "come to the light."

If we assume that the essence of the secret is the inverse of communication or simply the "negative communication," [58: 5] or perhaps "conscious concealment," [77: 321] we are confronted with the paradox that the most information-blocked areas create the most intense social need provided we want to dissolve the information vacuum, which has been created. The lack of answers to the relevant "why" question increases cognitive insecurity and the lack of information also increases the social tension caused by the lack of explanations. ${ }^{3}$ In addition, secrecy does not simply mean a subjective lack of information, but also requires the actual informant to intentionally become a "decoder", meaning that the possessor of the information deliberately conceals this knowledge. In such cases, secrecy does not simply mean deliberately obstructing normal communication processes, but also includes the active social relationship between them and the interaction of their conflicts.

At the same time, the relative and historical aspects of the nature of the secret are also visible. Different cultures, subcultures, groups, and institutions with varying demand for information, regard the lack of information as non-communication a secret. A substance, which was previously public, may later be protected by secrecy, while the reverse process is even truer: what used to be secret may later be deprived of this protection. It is no coincidence that Habermas (1962 trans 1989) derives the 18th century significance of the emergence of social publicity from the historical excess of the arcane and bureaucratic practices of absolutist state: "The apological literature defending the secrets of state thematised the means by which the prince could maintain the jura imperii, his sovereignty-that is to say, brought up just those arcana imperii, that entire catalogue of secret practices first inaugurated by Machiavelli that were to secure domination over the immature people." [23: 80] Therefore, with the strengthening of civilian communities, the practice of the Arcana is increasingly replaced by the principle of publicity. However, as the publicity of common

\footnotetext{
2 "You may have something that no superhero has." [[108]: 4].

3 It is the unanimous conclusion of the literature on attribution that inexplicability and incomprehensibility are as unpleasant and disturbing as when we are uncertain of our values. [26: 130-161].
} 
affairs becomes more self-evident, at the same time, on the other side of society, the tendency to protect autonomous secrets in the private sphere is growing: "What is public became more public, while that which is private became even more private." [85: 343]

According to Habermas, "The public sphere of civilian society stood or fell with the principle of universal access. The public sphere from which specific groups would be eo ipso excluded was less than merely incomplete; it was not a public sphere at all". [23: 126] In principle, everyone has the ability to participate in the public sphere of society. Reasonability, rational thinking is an anthropological (not class or order) property; "With the removal of the barrier that representative publicity had erected between laymen and initiates, special qualifications-whether inherited or acquired social or intellectual-became in principle irrelevant." [23: 65] Namely, common sense is sufficient for public participation. Competence is bound to normality. Anyone who is eligible under the prevailing definition of an era (such an eligibility criterion in most societies, such as adulthood, the competencies of writing and reading) is eligible as well for public participation.

Rationality is thus the second pillar of the public sphere of society alongside universal access to information. The public is constituted in the process of expressing opinions, arguably: the process of enlightenment, in which rationality is the "common façade" of the manifestations of different layers and interest groups, the general equivalence that enables the exchange of opinions at their argumentative value.

The third element of publicity seems to be substantial. In his book, Habermas elaborates on the process of separating the "private" from the "public", focusing on their structural fragmentation. The result of this process is the civilian public sphere. The direction of analysis, as the title of his book indicates, is not to describe the public sphere itself, but rather to determine its structural location. As a result, Habermas always keeps his eye on society as a whole to talk about a narrower topic. "The bourgeois public sphere evolved in the tension-charged field between state and society" he writes. [23: 204]

Bourgeois public sphere unfolds in the space of tension between the state and society, and certain people and groups have the power to control this border and to classify some of the public substance as non-public. Therefore, the secret is the insecure borderline between the public and the non-public. The secret itself is possible because there is a "preliminary" consensus classification of things in the public and private classes; only matter, which by their nature are public substance, may be considered secret. Thus, the concept of secret can be defined not by the substance but by the power aspect of the matter. In the interpretation of Habermas, publicity is debating over a matter; on the other hand, according to the mentioned thoughts above, publicity is about a kind of power struggle, which can be interpreted primarily through the categories of concealment and exposure of a matter.

Although the social-historical censorship of secrecy/publicity may be drawn - according to the Habermas interpretation above - along with premodernity/ modernity, it gives the impression that a persona in the power structure seems to be less sensitive to this increasingly wider openness. The secret service structure and activities, which form the hard core of the prevailing state-political institutional system; appear to be inert over time in response to changes in its social environment. 
Not all this is undermined by the increasingly public normative regulation of the activities of these institutions, the methods they apply and the gradual increase in their control. The traditional secret institutions are able to adapt to the rational-legitimate forms of government of modern social organization principles, mainly due to their strong cohesion attributions and the continuity of their instruments and techniques. ${ }^{4}$ If power is rationalized, the secret can also become rational-we can see it in Machiavelli. For him, the secret is already an inseparable mode of the practice of power, which operates continuously throughout the process. The Prince's author emphasizes not only the "raw" secret but also the importance of the "misleading appearances" associated with his structure. [44: 58] By Machiavelli and later on, the secret is almost "wrapping itself into the publicity", since on the one hand the misleading appearances are capable of filtering information and on the other hand provide a qualitatively different unrealistic opportunity to interpret phenomena, and thirdly they are resulting the fragmentation of the publicity. At the same time, the seemingly constant character of the secret services in itself, does not allow for the expansion of the dynamics of secrecy in such a way as to "recapture" the autonomy of the public sphere. [34: 80-81] Even if current political-power aspirations are temporarily capable of doing so, the democratic core values of the publicity will define a different direction in their relationship.

It is a very early recognition of knowledge theory that the thinking process itself cannot think for itself. [66: 149] Therefore, when we think of our consciousness, we are actually looking at some external sign of current thinking, thinking of the same phenomenon as the reflection of reality, or as an activity, that creates its own object. In both cases, we think of something that exists or has existed, that is, the outer sign of our current thought-as the specificity of matter, as a special connection between two objects, because of it, and so on. In such a case, consciousness is directed to a realistic process of reflection, and, when the question is asked, the answer is always the same. Thus, the "consciousness for consciousness" image of the "consciousness of reflection of reality" in humans is thus the repetition of the "consciousness of self-consciousness" phenomenon that the object of thought-reflection-has been enriched with yet another reflection. Therefore, no thought of any particular manifestation of consciousness is the thought of any aspect of reality reflected within us, no matter how far it has been abstracted from specific forms of reality. It is precisely this nature of consciousness that explains the fact that, by knowing the hidden conditions of thought, we can recognize the events, phenomena, relationships, and conditions that these states reflect.

\footnotetext{
4 The individual archetype of this adaptability is Joseph Fouché. Zweig writes in the preface to his book that Fouché's figure was brought to his attention by Balzac, who said the politician had "collected more power than the people of Bonaparte." So, Zweig became interested in the "brilliant chameleon," who began his career as a religious teacher, but 2 years later, in 1792, he plundered temples, who, as a representative of the people, nodded. Louis was executed, and a few years later he became a millionaire, and by the emperor's grace the Duke of Otranto. He served and betrayed Napoleon, paved the way for restoration, but after the Bourbons returned, he had to realize that he was a gray man again, as he was when he was young. [109].
} 
The position of a person seeking to reveal a secret - no matter what level - is a cognitive position. He is supposed to have some secret, and he tries to justify or refute this assumption. If this is not confirmed, the cognitive process is terminated. We have reconsidered a hypothesis and, to a certain extent, eliminated uncertainty in the horizon. We undertook the task of getting to know, but we didn't find out the secret, because there was no such thing, just a lack of information.

However, if the hypothesis is confirmed, his efforts to find the secret will be different. Immediately he seeks to know the features of the phenomenon called the secret. He will no longer check whether the object of interest exists or not. Entering into a special process of cognition, he begins to study, the purpose of which is not only to know something, but also to eliminate it as a fact. The cognitive person seeks to fully describe the object, thus as an object of cognition and as an object in general, he will "destroy" it. The "strange" or "alien" secret, once discovered, becomes our "secret," and thus no longer exists as our secret or another party's secret.

The bearer of the hidden state of the spirit represents the opposite-anti-cognitive-position of conflict. He carries some knowledge and tries to hide it from the secret seeker. If he succeeds, he will cancel an act of cognition, resisting the means of contradiction. Moreover, if the presence of a hidden mental condition has already been revealed by others, the secretary will at least try to thwart his efforts to describe the knowledge. In both cases, the performers are acting as rivals in a bilateral relationship-which is the hide and reveal - the pursuit of cognition and, conversely, the quest for cognition. In some cases, an interaction occurs, which in game theory is called a "zero-sum game", that is, what one player loses the other wins. [78: 56]

However, the loss and profit in this case is relative and, in some respects quite specific to all other losses and gains. In the rivalry between the carrier of the secret and the revealer, something that is elusive through abstraction can be lost and won. In the case of a successful reveal, the secret will not be the property of the searcher, but will simply be removed. In fact, it could be stated that by revealing the secret, some knowledge was passed on to the rival. However, this does not change knowledge in form or substance. Knowledge always remains knowledge, whether it is kept secret or not. Namely, it is not a secret. [58: 21] When the secret is revealed, the only effort that can be made to increase the damage is somehow, to limit its spread. From a functional point of view, the secret phenomenon remains specific to the collision of only two intentions contrary to normal communication conditions. In normal communication, the recipient remains passive while the communicator is the active party, both as a source of information and as an initiator of communication. In communication called secrecy, the two roles change fundamentally. Both parties do things they should not do in normal communication. The communicating party opposes communication instead of initiating it. It becomes a communicator to a "decommunicator". The recipient becomes a known but undesirable addressed of the communication. Many times, the recipient is searching for his own way of knowing what the addressed information does not communicate to him. The means of communication are also deliberately restricted, making efforts to not be a means of communication at all. Everything is directed against communication, even though all conditions of communication are available. It follows that the process of concealment, which we call secrecy, involves not only the lack of communication, but also 
the active and conscious retention of knowledge, in the form of secrecy, against a real or potential interest. ${ }^{5}$

Hiding the mental conditions presupposes, in most cases, a change in normal behaviour and, in the case of interest from the other "I", an active resistance to communication. In each of these cases, we are talking about different versions of lying. A lie tends to be defined as a moral or rather immoral phenomenon. ${ }^{6}$. In addition to moral relations, there is definitely a lie in politics, in art, and even in all of the selfcontained experiences of the standoffish selfhood. ${ }^{7}$ Logic defines lies as a mismatch between thinking and reality. However, there is no lie in the "object-subject" relationship. In addition, there are many false statements in logic itself, which, despite all logic, cannot be considered a lie. For example, is the widely known "lying" statement really a lie ${ }^{8}$

In the process, the author of the statement knows the truth, or at least the probability that his statement may not be true, but he persistently tries to mislead the addressed. In doing so, he seeks to distract his attention from the truth and thereby hide his own mental or spiritual state. Its purpose is to terminate an unwanted communication connection and replace it with another. Psychological and practical circumstances sometimes make the recipient active. However, no matters who is the active or passive party in communication, lying is always a relationship in which we intentionally conceal some knowledge and intent. Moreover, hiding thoughts and intentions is always an effort to eliminate an unwanted communication act. [55: 45]

The situation is similar in the case of deception, fraud, disguise, misinformation and every other form of secrecy. From this point of view, for example, misunderstanding can be imagined as a self-contained and imagined communication in which we ourselves have distorted the facts; misleading — masterfully realized lies; fraudan unexpected result for the recipient; silence-an unspoken lie because the recipient did or conceived what the communicator intended; distortion is the deliberate diversion of a given communication act from the subject; misinformation-partly true, partly false communication. In each case, we are confronted with disrupting or altering a communication process, with the originator of the communication seeking to hide his or her mental state. This means that the secret is not the state of a separate individual, but an active relationship between two parties in a relationship of conflict. 9

\footnotetext{
5 That's why Bok uses "dishonesty" in the same sense as "deliberate injustice." [6: 404].

6 "Is it possible to tell the unbiased truth about lies? Man is constantly struck with lies, however much he wants to avoid. As I recall, in my world life, I was taught that lying is a bad thing, we must always be honest."

[55: 7].

7 "Self-deception creates difficult definition problems. Is it deception or not? Intentional or unintentional? Is there any communication here? Recent studies of brain function show that this is not a case of deceiver and deception, but two different processes coordinated by the brain." [15: 405].

8 See Epimenides paradox: Epimenides was a Cretan who made one immortal statement: „All Cretans are liars.” This paradox can be also called the „Liar paradox.”.

9 "Anti-communist conscious influence assumes that people's perception of reality is distorted, its ideological-political knowledge, its moral and emotional state manipulated. On the other hand, consciousness manipulation presupposes a complex disinformation process that can only achieve partial results if the fact of manipulation and the internal context of the process of realization remain completely hidden
} 
Of course, conflicts are not always about secrets. However, if there is a secret, the conflict will be present a real or potentially hazard. The conflict is, in fact, the objective basis of the secret, a secret that is one of the manifestations of the conflict. Therefore, apart from the conflict situation, the secret can only be talked about conditionally, or as a reference to circumstances that are close to the secret in their form. Any deliberate disruption of communication results from some kind of conflict. Two participants of the secret-the initiator (the owner of the secret) and the potential recipient of the hidden state of mind-act as real opponents in a fight whose outcome can be defined, or at least related, to the disruption of communication. Essentially, revealing a secret is one party's success, while preserving it is the other party's success.

The owner of the secret always has certain advantages over the uninformed. The degree of erudition may be lower than others, but in some cases better. If this advantage is manifested among people in a formal or informal organization, it will inevitably become an exercise of power over someone. History and practice provide many examples where power was based on the mere possession of a secret, and the ruling authority was convinced that a person knew something more or something that was important but inaccessible to others. Secrecy is also one of the most important factors in the cult of certain individuals. In such cases, the paraselene of mystery is not only a natural accompaniment to power, but also a means of gaining it. In the realm of domination, the secret (hidden knowledge or intention) is not only an indirect but also a direct means of gaining power. ${ }^{10}$

Given the aforementioned characteristics of the secret-phenomenon, perhaps we need not have gone further from the afore mentioned Wittgenstein-axiom, which was supposed to see and portray in language only one meaningful use of mapping facts. It turns out that the language of the secret services is a means of disinformation, which is constantly intended to consciously conceal and hide facts, partly to preserve its own secrets and partly to influence the opposing party, to develop a false attitude and to make manipulated decisions.

The appearance of the written version of the secret of the secret service language, the cryptography, coincides with the appearance of the writing itself. In some respects, the era of the wise division of labour coincides with the beginning of the

Footnote 9 (continued)

from the target persons and target groups. This is partly because the sharpest part of the implementation of conscious manipulation has come into the hands of the imperialist secret services, and partly because they have the secret means and methods by which the fact of manipulation can be kept secret" - writes the state security literature. [60. 134-135].

10 "Sharing information is one of the most important symbolic expressions of political position and prestige in any dictatorship. Although somewhat offended, Vladimír Farkas, who was the head and then deputy leader of the National Protection Authority's cross-border reconnaissance organization, drew a credible picture of this in his memory, and from 1950 to 1953 he was also a member of the State Security Authority College: "I considered it a ridiculous manifestation of mistrust in the country that I, as the head of one of the most important departments of the State Security Authority, did not get access to MTI's confidential information reports, which primarily contained news from Hungarian-language foreign radio broadcasts and the press. It is true that more and more Hungarian emigrate press products were available to me at that time." [18:34, 72: 8]. 
writing era, with the discovery of a way to deliver important news to their destination by interlaced messengers. This relay messenger system evolved first in the Persians, then used extensively by the Greeks, but it also evolved into an entire system in the some of the most remote countries and parts of the world: China, India, South America. The acquisition of these documents was henceforth the most important task of the spy organization in every state, and cryptography, which made the substance of the documents indelible to strangers, was quickly developed to counteract them. The essence of cryptography is that although the substance of the message is real, only the target person can decipher the information that is encrypted. Until now, Caesar cipher is the correspondent method in which Julius Caesar used to tell the number of letters in the cipher besides the secret message. From a linguisticsubstantive point of view, cryptography is no different from public speaking, since only the formal-morphological aspects of the system of expressing ideas become secret. [3, 17, 42, 46, 69]

Similarly, the formal aspects of the secret language were represented by codes, abbreviations, numbers, and symbols that blocked not only enemy forces, but also uninitiated persons within the services from information, documents, files, target persons, and objects; they wanted to make identifiable collaborators and operations outside. One of the most well- known markings in the secret services world is MI5 and MI6. Elizabeth I of England commissioned Sir Francis Walsingham to set up an imperial secret service in 1568 to deal with the impending external and internal threats. This organization had operated from the outset within the army, serving as a ground and maritime intelligence service. In 1910, as part of preparations for the World War, "civilian" services were set up to carry out external intelligence and internal counter-intelligence tasks. At the same time, remembering their military origins, they retained the flag in their name, leaving Military Intelligence in their name and MI5 for the domestic division and MI6 for the espionage (at that time in Ireland intelligence was conducted by the Scotland Yard Special Division). [94: 102]

In Hungary even between the two world wars, similar marking was used by the Central Investigative Command Staff Subdivision to assign-the Group "A" of Ministry of Defence (hereinafter referred toas MoD) Department VI-2 - the Intelligence and Counter-intelligence Centre of the MoD Chief of Staff-Department VI-2, and later simply Department 2. After 1953, the supervision tasks of the State Security Authority within the activity of counter-reaction in ideological and scientific areas had returned to the fundamental responsibility of the Ministry of Internal Affairs, and they were providing for Department 4 of General Department IV, even the economic-intelligence tasks had been designated immediately before the change of the regime to Department II/I-14. Following the infamous "Danube-gate" interception scandal in the year of the regime change in Hungary, public opinion throughout the country knew that the State Security General Directorate III/III Department had the task of political counter-reaction, but decoding the other cover numbers remained largely unsuccessful. [73]

Moreover, more mysterious is the generation methods of the alias or cover-name of the people in the agent network (agents, confidents, and clandestine staff). The cover-name was given by the case officer at the time of recruitment, included not 
only on the 'File No. 6' - which was used for documenting his recruitment -, but also in the work file containing his reports and in the record of all operational measures with which he had been involved. There were no more detailed rules in the terms of "aliasing," but obviously the recruited person could not use his own name as a pseudonym, and the given cover-name could not be offensive, disobliging, or in any way an opportunity for de-conspiration. [54: 191-194] Initially, the covername had been chosen using the names of historical figures ("István Széchenyi”), former politicians ("Pál Teleki") or widely known artists ("Katalin Karádi"). However, a 1964 deputy interior Minister's order put an end to this practice: "The person being recruited should be consulted on the use of the cover-name. In most cases, the cover-name is chosen by the recruitment candidate himself from a set of alternatives provided by the case officer. It is forbidden to choose or give the names of prominent figures of historical and public life or of cultural history. ${ }^{11}$ Interestingly, Russian emigrants from the Soviet system frequently travelled under the pseudonyms "Ludendorff" and "Horthy" between Munich, Vienna and Budapest in the early twenties. ${ }^{12}$ In addition to the cover-names of the agents in his network, the secrecy concerned the designation of the target person, the target objects, but also the operative designations of cover works, cover stories ("legends"). [51: 62]

However, covert communication with language symbols primarily contains peripheral elements of the secret service language. [51: The true nature of the language concerning the secret services can be learned mainly from the regulatory environment, from the pursuit of the institutions, and of course from the related files and documents. However, it is difficult to fully recognize the regulations of the secret services or their applied language because these regulations are, by their very nature, only in exceptional circumstances available to the public. The general public are forbidden access to the overwhelming majority, or the most important parts, of the wide range of internal norms and ordinances. With all these complex research conditions in mind, it seems essential to clarify who is communicating with whom, when, where, and for what purpose. One of the tasks concerning the interpretation issues of agent files considers the following aspects essential for understanding the communication situation in which these reports have been created: [90: 7-59]

- It is worthwhile to distinguish between the author and the narrator, which in the case of network reports has the dual name of the citizen and the cover-name, and whose relationship is far from problematic. The "voice" that speaks on the sound recording belongs to the name that authenticates what it is written: the agent's; even if, in the historical discourse, the self of the agent cannot be completely separated from the self-designated by the civilian name.

- Speech is always for somebody, and during the speech, we always take into account the perceived or real expectations of the real or virtual audience. Thus,

\footnotetext{
11 Order No. 001 of the Deputy Minister of the Interior of the Hungarian People's Republic, February 12, 1964. [61:21].

12 Hungarian Military Historical Archives. Directorate of Military Staff II. group. 702/403. ny. — 1920. and Directorate of Military Staff. I. group. 266/hdm. — 1921. In: 13: 488-489.
} 
the audience exercises "control" over the speaker to such an extent that most people regard him as a co-author.

- The agent did not write (orally present) his report during the observation, but afterwards, his narrative was necessarily retrospective. Thus, the act of memory cannot be bypassed when reading and interpreting agent reports. Monitoring, storage, retrieval-no hassle-free processes.

- Recalling circumstances greatly determine what someone talks about and how. One of the main findings of the science of memory is that memories are formed when they are evoked, they are created.

- The context basically determined by the goals of state security and by what the reports were about and what was left out of them (i.e. what the agent was experiencing). The question is how well the network agent was aware of the goals of state security. In addition, the agent's goals should not be overlooked. Not only did the state security use the agent network, but its members also sought to exploit the situation for their own purposes.

In any case, the author of this study notes in advance with regard to research, that:

1. The secret services, by virtue of their close proximity to power, shall at all times be direct or indirect representatives of the dominant ideological value system in their language.

2. As a result, the language of the secret service is multiplied. Public speaking can be more propagandistic, and internal language can be more professional.

3. There may be a significant additional difference between the speech actors in terms based on inequality and their relationship to power.

3.1 The style, vocabulary, and objectivity of internal commands for subordinates within an organization are obviously different than:

3.2 A preparatory interview with a recruitment candidate or,

3.3 A handwritten agent report or,

3.4 The confessions and records of interrogations or,

3.5 The propaganda materials addressed to the public, created by the secret service, and

3.6 The text of operational information intended to mislead the enemy/opposing party. $^{13}$

\footnotetext{
${ }^{13}$ Активные мероприятия (Meropriyatiya aktivnyye) - Active measure: Operational measures to influence intelligence-relevant aspects of political life in a target country, including addressing foreign policy and internal issues in an intelligence-related manner, misleading, weakening or undermining the opponent positions, and destroying enemy plans, and achieving other goals. [57: 206].
} 
4. Due to the complexity of the secret services, the language of military intelligence/ counter-intelligence agencies tends to have an affinity for the terminology of the military and contains specific elements of the general secret service language. ${ }^{14}$

Henceforth, the study intends to use the methodological considerations mentioned above, in order to examine and present the linguistic changes of the State Security Services of the 20th century's Hungary from the Hungarian Soviet Republic (March-August 1919) through the Horthy period (1919-1945) to the One-Party System (1949-1989).

\section{The Hungarian Soviet Republic (March-August 1919)}

The Horthy era's Soviet Republic discourse from 1919 to 1944, or, to put it simply, the "speech" of the Hungarian Soviet Republic, organized around the subject of judgments of the proletarian dictatorship, has thus far not been explored with a monographic need. [14: 10-12] In addition, we can add that the number of nonmonographic works is small and this seems to apply to the whole examination of the secret services regardless of the era.

First, it is crucial to the initiating of the research to take note of the changes of the language of the Hungarian secret services, that in the era of Dualism the secret service organization of the Austro-Hungarian Monarchy was the Evidenzbüro (Registry Office). The name itself was a pseudonym, and it was intended to cover the military intelligence organization of the dual-state. The applied language within the organization was German, of course, but primary reports from the monarchy's nationalities and from abroad came in other languages as well. At the same time, Hungary also carried out independent counter-intelligence activities, with the establishment of a state police department within the MIA, focusing to monitor primarily on the political parties and nationality movements. [68: 93-125]

In 1912, as a visible sign of preparations for the First World War, the MIA enhanced the censorship of military-related newspapers: "As some newspapers have published articles on military operations that, in addition to unjustifiably disturbing the general public, by providing clear information about the mobilization and manoeuvres concerning the Royal Army: The Hungarian Royal Ministry prohibits all news releases regarding the status, manoeuvres, strength and operation of the armed forces, the status of fortresses and fortifications, as well as the quantity of weapons, warfare or equipment and the quantity and quality of rations." This decree was addressed mainly to the editor-in-chief of the newspapers, but after the

\footnotetext{
${ }^{14}$ For example, military language speaks of "reconnaissance" rather than "intelligence", while the use of "psychological operations" is the same in the language of civilian and military intelligence services. [59: $55,47,76,96]$.
} 
enhanced censorship, due to the lack of information, fake news and guesses had naturally appeared in the public speaking arena. ${ }^{15}$

Just before the beginning of the First World War, the issue of the use of the language of the Evidenzbüro came to the fore again. The meeting took place on May 18, 1914, with the participation of representatives of the Austrian and Hungarian Royal MIA. The participants agreed on the foundations for cooperation between civilian and military authorities, defined the way in which the central offices were to operate, and the reporting obligations and designated German as the organization's language. [85: 74]

After their defeat in the war, on 12 November 1918, the Austrian government disbanded the Evidenzbüro, parallel to the downsizing of the Ministry of War, the Austro-Hungarian Monarchy's secret service had ceased in days. In Hungary, the government formed on October 31, 1918 under the leadership of Count Mihály Károlyi left the structure and practices of the MIA virtually untouched. At the same time, fully identifying with its democratic program, the Metropolitan State Police immediately joined the National Council, which consisted of the members of the Party of Independence and 48' of Károlyi, the Hungarian Social Democratic Party and the National Civic Radical Party. The text of their elevated proclamation is not devoid of direct political stance: "The officers and detective corps of the Hungarian Royal State Police of the Capital, the undersigned, on behalf of the officers, detective and security staff of the State Police, with unanimous enthusiasm, with all the warmth of our patriotic spirit, welcome the Hungarian National Council as the sole representative of the will of the Hungarian people. We will also announce the joining of the officers, the detective body and the security staff. This decision is what drives us to the traditional royal loyalty, democratic feeling of the nation, and the overriding, overwhelming interest of the defence, the destiny of the homeland. We consider it patriotic to declare that we wish to ensure the order and tranquility of the capital of the country and ask the National Council to support us in this work with all his might."

On behalf of the National Council, Mihály Károlyi responded to the delegation: "He was warmly welcomed for taking such a brave step. He knows how much courage had taken to make that decision. He knows that they did this precisely because they do not want a civilian war, they do not want Hungarian blood to be spilled here inside the country. He asks them to do their duty courageously and honestly to uphold the internal order, but in such a way as to avoid any conflict. In addition, if the people see that the police are not the enemy, then it will be easy to maintain order because they will listen to them. They will listen because they know that the Budapest State Police is no longer in the service of the reaction. Nevertheless, the newspaper Népszava (People's Word) saw other motifs in the rapid change in the rhetoric of the State Police, which "the previous day had shot in and infiltrated the peacefully protesting masses. It seems that the great public outrage over the clueless bloodbath has made them think and realize that they cannot confront the new

15 The Royal Hungarian Ministry's 6966 M.E. Decree of 23 November, 1912 on the prohibition of publication of military measures in the newspaper. [27: 216]. 
and irresistible currents of modern times without the risk of being swept away and destroyed." 16

A new term has also been added to the State Police dictionary. According to the related documents, what happened at the end of October was first called the "revolution" by the Office of the Chief of the Budapest State Police, when he presented his monthly report to the Administrative Council of the Metropolitan Council on December 16, 1918: "A retired lieutenant was commander of the city of Budapest in the early days of the Revolution, and later commander of the National Guard Naval Detachment, on suspicion for fraud, misdemeanour treatment, embezzlement, conspiracy to commit murder, etc. having been remanded in custody." Furthermore, a study written by György Auer about the summary report of the Hungarian Metropolitan State Police entitled "Our Police before the Revolution" and was published in the December 1918 issue of the Hungarian Journal of Legal Science."

It is also interesting from the point of view of communication history that when the Minister of Defence on December 21, 1918, informed the head of the MIA he stated that he would hand over the entire staff of the Propaganda Department to the MIA. However, Interior Minister Vince Nagy rejected this suggestion [8:6], because according to his equation; the ministry does not need propagandists. ${ }^{17}$ Indeed, the people's law on "state protection", which most affected the activities of the secret service, also omitted all political, historical and ideological texts. ${ }^{18}$ The turnaround three months later, with the announcement of the Soviet Republic at this point, resulted in the most significant change in the communication of the secret services.

Moreover, the emergence of modern political propaganda was linked to the First World War, which had a catalytic effect on the generalization at the end of the war and a series of revolutionary events that followed. [4: 16] The term "total propaganda" had not yet become naturalized, but its main characteristics are at this time obviously recognizable. It simultaneously addresses the individual and the mass, and seeks to make a lasting impact in the social realms beyond politics, and its toolkit is effectively integrated into the state structure and into the world of politics and the media. [35] The study of József Balogh, published in Gusztáv Gratz's first critique of the Soviet Republic, states: "In the old state, propaganda is the » incognito «tool of flexible and wise diplomacy, here an institution of dictatorship that is adamant, rude and primitive like the symbolic proletarian fist." [2: 34] At first glance, compared to the "wise and prim" propaganda of the 19th century, the "rude and primitive" toolbox of the early 20th century's propaganda is really astounding; however, József Balogh's attention was probably deflected by a series of artistic expressions that were expressive at the time. From the beginning of the 20th century, as a sign of protest against civilian society and war, they aimed "to express their feelings and

\footnotetext{
16 Népszava, (Hungarian daily newspaper) October 30, 1918. 1. 7. p.

17 National Archives of Hungary, K 148, 1918-4-10963. [56: 6].

18 The National Council of Hungary adopted the following People's Decision in the XI. People's Law on the Protection of the State Form of the People's Republic. Approved by the President of the Hungarian People's Republic on February 10, 1919. Promulgated in the National Legislation on February 11, 1919. $\S 1$. "Anyone whose act is directly aimed at forcibly altering the form of the state of the People's Republic of Hungary is punishable by a term of imprisonment ranging from 10 to 15 years." (...) [21: 22].
} 
ideas about reality directly, without restraint”. [1:248] It was not even a coincidence, that Tristan Tzara published his famous proclamation at that time in 1918: "I demolish the compartments of the brain and the branches of social organization: everywhere, the hand of providence must be shut down and hell, the eyes of hell must be put on the sky, the fertile cycle of the universal circus must be restored to real power and individual fantasy." [98: 27] However, radical politicization has recognized and used the mobilizing potential of avant-gardism it is enough to think of Mihály Birós red-hammered worker figure, (originating from 1912, made for Social Democratic Party).

In a debate on the "Law of the Order" of 1921 (to be discussed later), Endre Csukás, National Assembly Representative from Öriszentpéter, interpreted the relationship between art and revolution in his own way: "This matter is a special kind. You are always dissatisfied if you cannot divorce and come up with things that border on perversion and run counter to common sense. For example, in painting, Cubism, or Futurism and the like. The same is true of literature... Westernism."19

Naturally, because of the fusion of the Hungarian Social Democratic Party and the Communist Parties on March 21, 1919 the Socialist Party played a leading role in defining political, ideological and direct propaganda activities. The coming of the World Revolution was one of the most important foundations of the leaders of the Hungarian Soviet Republic and, consequently, of propaganda. This belief permeated the propaganda and was constantly featured in the press and other material's topics as well. [86]

The constant emphasis on the working classes' historic vocation sought to recognize the legitimacy of revolutionary violence: "Power is in our hands. Anyone who wants to return to old rule must be ruthlessly hanged up. One has to bite into the throat of this kind. The victory of the Hungarian proletariat so far has not suffered any particular casualties. Now, however, it will be necessary to shed blood. There is no need to fear blood. Blood-steel: strengthens the heart, strengthens the proletarian fist. Blood will make us great. It will be the blood that leads us to the true commune world. We will exterminate, if it is necessary, the whole bourgeoisie!" [11: 33]

The first step toward the institutionalization of propaganda at governmental level of the Hungarian Soviet Republic was to create the Department of International Propaganda of Socialism within the framework of the People's Commissariat for Foreign Affairs. The long-term internal goals of the propaganda work were to be formulated and implemented by the People's Commissariat for Public Education itself. This latter governmental body's Group VII was specifically called "the State Propaganda of Socialism." Its designated tasks_-Scientific and Popular Propaganda; Workers' Academy; refresher courses; youth worker propaganda-had indicated from the outset that it had sought to oversee cultural, scientific and educational life as a whole. According to a press release: "At the intent of the Revolutionary Governing Council, the People's Commissariat for Public Education has set up a propaganda group. This propaganda group is one of the organizations of the proletarian

${ }_{19}$ 164th session of the National Assembly March 14, 1921. National Assembly Diary, 1920. VIII. Vol. 17, February 1921-March 14, 1921. 583 p. 
dictatorship and its task is to spread socialist ideas in the widest possible range. As part of his work, it uses agitation papers. It publishes educational books, handbooks and textbooks of higher education institutions, and textbook processing of the material presented at the party school. There is a separate department responsible for the 'folksy' publications for the poor-agricultural individuals, separate papers are made for women, and even a separate department deals with the domestic and foreign literature. Another dedicated organization to agitation is the Agitator School, which provides three types of courses for those skilled in socialist literature and agitation; Planned Agitation is taught in a separate course."20

To protect the proletarian dictatorship, the Revolutionary Governing Council gradually established several armed and law enforcement bodies, replacing the gendarmerie with the Red Guard, established on March 26, 1919. The latter functioned within the framework of the People's Commissariat for Internal Affairs, but there were also a number of self-governing bodies ("Lenin boys"), led by József Cserny, who initially identified themselves as the "Political Terrorist Team". [53:49] Finally, the Revolutionary Governing Council, at its meeting of July 17, 1919, adopted the resolution of the party's previous day's meeting, which stated, that "the Fabik-group (...), under the auspices of the National Red Guard, should be organized as an insurance team." [100: 492; 102:60]

The functions of the Political Police were carried out by the Political Department of the National Guard of the Red Guard, which was later placed directly under the People's Commissariat for Internal Affairs, which was responsible for establishing a national spy network and directing and controlling extraordinary procedures. [100: 212]

An addendum to the form and substance of the Red Guard's internal communications is a daily command issued by Fülöp Weisz in response to a coup attempt against the Hungarian Soviet Republic on June 24, 1919, to his crews and their commanders (literal citation). [5: 81-82]

"Informative communication to the crews of my command and their commanders.

At 5 o'clock yesterday afternoon, I went to the division headquarters. As I approached the Chain Bridge, three monitors floating on the Danube with a national flag had appeared. They cruised up and down the Danube and then fired machine guns on the former headquarters building. I was at the headquarters at that time, where 14 former officers were later brought in, who committed so effrontery as quality of » commander-in-chief «, that they deceived the crew in the artillery barracks.

As if they were acting on the orders of the People's Military Commissariat, the deceived crewmembers were ordered to shoot the bridgehead in Újpest. They also fired approximately 16 shots, but soon the crew realized they were being misled by the hooligan pigs, all of them have arrested except the two

${ }^{20}$ State propaganda for socialism. Pesti Napló (Hungarian daily newspaper), 25 April, 1919. 7. p. 
panders, who managed to escape, but they had soon captured and had taken into custody. Here, just during their interrogation, they suddenly started firing a machine gun at the divisional headquarters, and these two bestial bastards grabbed a gun during the mess, but before they could be used, with one shot for each, I brought them down at the scene.

Comrades! When it comes to our principle, a few hundred corpses are nothingness!

That is why my comrades only have the courage and perseverance and the unshakable adherence to our ideas and principles, then our victory. Long live the real proletarian dictatorship!

\section{Political commissioner Weisz"}

Captain Jenô Lemberkovits, who was also accused of counter-revolutionary activity, was shot to death in the office room of Fülöp Weisz. [92: 69] Incidentally, during the Soviet Republic's martial law proceedings, a total of 115 death sentences were passed and all executed. Of these judgements, 12 were executed for common crimes, 2 for military crimes, and the other 101 were executed for political crimes. [75: 77]

Relevant legislation often included calls for the historic necessity of the proletarian dictatorship, the revolutionary role of the working class, the task of abolishing the exploitative capitalist class and overthrowing the bourgeois state. From this, legal norms sometimes took the form of political revelations. For example, the law justified the criminalization of the abuse of public authority with the following ideological rationale: "The moral of communism requires the suppression of individual interests in the service of the proletarian public interest to those who have been entrusted with the exercise of advisory power. For this reason, the full severity of the penalty power of the proletarian state has been imposed on those who abuse public authority for petty individual interest." 21

The Revolutionary Governing Council's decree of late March 1919 on the formation of the Red Army emphasized: "The Red Army is a proletarian classes' army. It is an equal duty of every soldier to defend the interests of the revolutionary proletariat against all external and internal enemies, to fight for the liberation of the world proletariat." (Citated by Vörös. [103: 86])

In addition, the regulation of the Revolutionary Tribunal resulted directly in wording appropriate to the genre of political propaganda ${ }^{22}$ :

"The proletariat can only count on victory in its life-struggle against exploiters if it is fought with unity and strength. Therefore, anyone who acts on his own initiative and acts violently or threatens, both individually or in groups, undermines the unity of the proletariat and endangers the victory of the proletariat.

\footnotetext{
${ }^{21}$ Abuse of public authority. Order No. 1 of the Allied Central Manager Committee. Republic of Councils, Issue 81 of 2 July 1919. Citated by Sarlós. [75: 82].

22 Bring the arbitrary actors to the Revolutionary Tribunal. Revolutionary Governing Council's No. XLII decree. Republic of Councils, Isssue 13 of 9 April, 1919. Citated by Sarlós. [75: 65].
} 
The proletarian dictatorship does not mean the dictatorship of some people or groups, but that the whole proletariat, in its unity, forces its will on the exploiting classes. This will is exercised by the proletariat through the Revolutionary Governing Council until a national congress of councils is formed. Thus, anyone who opposes the will of the Revolutionary Governing Council or takes unauthorized violent measures without the authority of the Revolutionary Governing Council confronts the proletarian dictatorship itself and is a traitor to the cause of the proletariat.

The Revolutionary Governing Council thus orders that a Revolutionary Tribunal be brought before anyone who acts autonomously on matters falling within the remit of the Revolutionary Governing Council, the individual commissions, or the authorities appointed by them.

Those who use unauthorized armed force (guard or military) are particularly severely punished.

The Revolutionary Tribunal may impose the death penalty.

Budapest, April 7, 1919."

Just as the ideological-political foundations of the entire functioning of the Hungarian Soviet Republic were determined by the Soviet-Russian model, so did the legislation of the Hungarian proletarian dictatorship on symbols, taking into account the characteristics of the Soviet legal system. In both countries, the new power abolished the titles and ranks of the previous system, in virtually identical terms ${ }^{23}$ :

"There is no nobility, rank and title in the Hungarian Soviet Republic; there are no orders of honour or other similar. In addition, there are no titles, which merely express the rank of official (e.g. secretary of state, council of ministers, secretary, etc.). Civilian servants are given the official title used to describe professionally the work associated with their position (e.g. group leader, department head, librarian, typewriter, etc.). These designations are defined by the individual Commissioner in each administration.

Budapest, March 25, 1919

\section{Revolutionary Governing Council”}

The imitation of the soviet-model continued in the world of political symbols. Tibor Szamuely, Commissioner for Public Education, prescribed the exact scenario for this: "First of all, we will remove all the old-bad statues of our city. Instead of four unsightly king statues of Körönd (nowadays Kodály Square), we will create four groups of statues that will serve as the pedestal of a nine-meter-wide flaming

\footnotetext{
23 It can be seen later that these symbolic measures were among the first measures both of Szálasi and, after 1945, the Provisional National Government. The abolition of orders and ranks. Revolutionary Governing Council's No. VI decree. Republic of Councils, Issue 1 of 26 March, 1919; Decree of the All-Russian Central Executive Committee of the Council of the People's Commissars on the abolition of orders and civilian ranks of 11 November, 1917. in: 38: 131.
} 
globe that will float above the centre of the driveway. The centre of the millenary memorial at the end of Andrássy Avenue will be transformed into a red obelisk. The columns around it are also properly decorated. Instead of the ugly sculptures that were placed there, this colonnade will turn into an allegorical work. In front of the obelisk, we set up an eight-meter-high statue of Karl Marx, two work figures on either side. At several places in the city, we also erect statues of Karl Marx, slightly smaller than five meters, and statues of Lenin, Ervin Szabó, Károly Liebknecht and Friedrich Engels. The City Park Industrial Hall is completely red-clad, with friezes and ornamentation. Andrássy's statue on Parliament Square will disappear, and the Greek-style temple of Work will be built above it. We place various ornaments in the Castle, on the Gellért Hill Citadel and in front of the Anker Palace. All of these works serve a dual purpose: on the one hand, we raise the importance of the ceremony and give fun to the proletarian masses involved, and on the other hand, give a large number of the unemployed a job for a few weeks. (Cultural propaganda in the Red Army. Budapest's artistic ornament on May 1st. [87: 8])

Much of these plans were, in reality, accomplished, and the traditional red flag of the labour movement was completely expropriated by the proletarian dictatorship: "The capital of the Hungarian Soviet Republic had dressed in so a red ornament on May 1 that we could not imagine in our dreams. The world of fairy tales came to life before our eyes... red everywhere, only in red. There was no side street or alleyway where even a single hut lacked the red flag. The windows of the poorestlooking houses were adorned with red five-pointed stars, various symbols of work, and revolutionary inscriptions. Opposite the entrance to Andrássy Avenue, the largest March on the corner of Spa Street, there is a huge red triumphal gate with the caption » Destroy capital to build the world's international communist society «. The four »king «statues of the Körönd are occupied by huge red globes, surrounded by a garland of columns. The opposite end of Andrássy Avenue, the column of the Millennium Monument in the city park turned into a giant red obelisk staring at the sky. The semicircle of the memorial pillar also bears the inscription red, » Workers of the world, unite! «. On the shores of the Lake of City Park, Marx's name is proclaimed in huge red letters. At the intersection of Kossuth Lajos Street and Museum Boulevard, two gigantic masts swing with rich red ornaments. The Baross statue was covered with huge red wheat with huge five-pointed stars. The statue of Lenin stands in front of the red-covered fish hall. Above the castle, the former Habsburg palace is adorned with a red ornament and the crown at its highest point is covered with a red veil. On the Pest side of capital, the enormous, illuminated» Red Man «from the Palace of Commerce Bank raises his hand to strike down." 24

However, "red" also became the most important adjective in the dictionary. Following the Russian example, not only the stars and the flags became red, but also the army, the guard, the regiment, the soldier, the newspaper, and even the technical dispatch rider. $^{25}$

${ }^{24}$ Budapest dressed in red. Népszava, (Hungarian daily newspaper) 3 May, 1919. 6. p.

25 "Members of the red messenger group usually receive red salaries." Népszava, 25 May, 1919. 
"The sharpest confrontation with the events of 1918-1919 provided the constitutive core of the Horthy era's » counter-revolutionary identity «: the history of the oppressive proletarian dictatorship and the rise of it functioned as the mythical»foundational story «of the counter-revolutionary system. This » sharp confrontation «can also be traced well in the changes in the language of State Security Service of the period." [14: 12]

\section{The Horthy Era (1919-1945)}

Under the leadership of Miklós Horthy, the "counter-government" of the above mentioned Hungarian Soviet Republic, the Counter-Revolutionary Government of Szeged had in parallel created its own, different intelligence service. The Group II of Supreme Command, which was actually the military intelligence service, had consisted of the National Army Registry Division and the MoD Intelligence Department. Despite the restrictive measures of the Treaty of Trianon, the High Command, the military intelligence and counter-intelligence continued to operate covertly as MoD (Military) Main Group VI or rather the 2nd Division of Main Group VI. From 1938, the military intelligence and counter-intelligence body further operated as the 2nd Division of the Chief of Staff of the Defence Forces. At the beginning of the Second World War, in the early 1940's, the Press and Propaganda subdivision of the fifth Division of the Chief of Staff of the Defence Forces also regrouped into the second Division. [7: 72]

In the framework of civilian activities, the military state security organizations were essentially responsible for the detection of the harmful endeavors of Little Entente-states, as well as for the counter-measures against the extremist ideologies and movements (communism, hungarism). However, the radical elements at this time could also be opposed by the Political Police Department of the State Police (between 1920 and 1932 under the designation of Main Group of Political Investigation) and the Central Investigation Command of the Gendarmerie. In view of the war situation, the State Protection Centre was established in 1942, its main task was to coordinate the work of certain internal security agencies. [24: 391-395] Following the German occupation, a decision was made to set up the State Security Police. After the Arrow Cross Party's takeover of power, the State Protection Centre was soon disbanded. In early November 1944, an organization called National Impeach, was established to investigate crimes against the pro-Nazi, hungarist government. [40]

Essentially, the Marxist-Leninist ideological rhetoric of the Hungarian Soviet Republic was considered by the secret services of the Horthy era as counter-functionalizing hate speech; the Christian-national and anti-communist rhetoric had become the fundamental values in their political communication.

The government under Gyula Peidl, which came to power on August 1, 1919, and was considered only transitional, began to withdraw communist decrees by language policy: Hungary was renamed; instead of The Hungarian Socialist Federal Council, it became The Hungarian People's Republic, (the name of the country under the former leadership of Mihály Károlyi,). In this context, Government Decree No. 3 was 
already more politically charged, according to Article 1: "The prosecution, which started the current year on 21st March and finished on 2nd August, as of an act of a political nature, must be terminated. Those who are arrested for such acts shall be released."

The literature of party historiography after 1945, first and foremost described Horthy's path to power propagandistically by describing the reprisals and atrocities committed by paramilitary detachments based on real events. "And the terror continued to rage further. In Budapest and in the countryside, especially in mining settlements and industrial centres, police force units were even more ruthless. No one disturbed them in their truculence. When one or another of their evildoing indicated too much indignation in the country, they carried out some kind of 'make-believe' criminal proceedings rapidly, which usually ended up with the acquittal of murderers, who were not found guilty by the prosecution. But Horthy himself was the foremost protector of the murderers." [63: 53] The excesses of the stylistic emphasis may have been due to the real atrocities that had taken place, as confirmed by an onsite report from the British Trade Union Congress and the labour Party's delegation: "During our inquiries into officer detachments - these are the bodies accused of systematic cruelty - we were informed that some of the squads' conduct was excellent. In case of other detachments, however, it seems true that prisoners are beaten, tortured and murdered. In our opinion, the government should have placed this detachment under the control of the civilian authorities and, in particular, led to the atrocities that it failed to do so. In this regard, it should be borne in mind that disarmed officers keep their uniforms and swords, and it is likely that terrorist brigades are made up of these former officers who are not members of the detachments; however, disbanding them would also make it more difficult for terror brigades to operate. Nor can we ignore the assumption that personal vengeance and the possibility of plunder also play a role, and since victims do not know whether or not they were raided by the police force protected by the military, they find resistance useless, inasmuch as violence against military officers is one of the most serious crimes. " [104]

Indeed, for example, with regard to the cruel acts of one of the most well-known figures in white terror, Iván Héjjas, a gendarmerie prosecutor made the following decision to terminate criminal proceedings based on the official judgment of the period:

"As the suspect, according to the prosecution, he acted under the influence of intimidation and excusable indignation purely as a result of acts purely against the Hungarian race and national idea, and in the false belief that his act served the cause of the prosecution, there was no evidence to show that the suspect was guilty of selfish gain in the commission of his act; therefore, in view of the fact that the preconditions for a pardon provision are met, he should be pardoned and the criminal proceedings should have been terminated." 26

Comparing the proportions, social agenda, background and legitimacy of the two types of terror, the red and the white, it turns out that the 'red' was progressive and

\footnotetext{
${ }^{26}$ Decision of the Prosecutor of the Hungarian Royal Gendarmerie in the case of Mihály Franczia Kiss and his associates. December 18, 1924. [57: 276].
} 
utopian-it wanted to create a world of fire and iron that was fundamentally different from all that previously existed. Moreover, it was willing to sacrifice concrete people for the vision of this more humane world. The 'white' was retrograde, and ultimately utopian-it was convinced that there was a stable social order, based on ancient morals, that needed to be returned and all those who refused to be disciplined or intimidated, may need to be exterminated." [37: 91]

Under the consolidation efforts of the Bethlen period [97], the secret service organizations - the Main Group VI Division 2 of, the State Police Political Investigation Department and the Gendarmerie Central Investigation Command-also tried to move its activities from retaliation to law enforcement, while the dominant enemy line had shrunk into a communist movement that had been fragmented by retaliation and emigration. A typical example is the decree of the Minister of the Interior Iván Rakovszky, delivered on 6 September 1922 to subordinate officers of all subdivisions. In the decree's introduction, the Minister gives a personal summary of the political situation ${ }^{27}$ :

"I have recently been concerned about the heavily spreading of 'unnationalistic' movements in the country. Thus, it can be stated that the Socialists (social democrats) not only develop and propagate their organizations at the industrial focal points and colonies, but also organize themselves feverishly in the countryside. These machinations fueled mostly by foreign communists.

In order for public security authorities and bodies to successfully fulfil their important function in the field of state security and national defence, I shall order that all arrangements and efforts to dismantle national unity, especially secret socialist (communist) agitation in the countryside, be followed with the utmost attention and against the organizers and instigators of this kind of machinations, strict action must be taken. In doing so, everyone must keep "vigilant" attention on those individuals who wear or red colors - despite the existing prohibitions - in a manner reminiscent of internationalism, or who carry expressly communist badges. Of these, those who wear well-known, specifically communist symbols (five-pointed star, red button, red ribbon, etc.) either will, depending on the circumstances, be subject to the interrogation procedure or be placed under police supervision. Rallies, which are of concern to public security or national defence, may not be allowed at all. On still authorized or acknowledged rallies, the commissioners must ensure, among other things that the formerly reported subject-series of the meeting are strictly observed and that politics is not dealt with a meetings concerning economics, and statements are contrary to public policy and to the prestige of the authorities should not be made. Finally, a detailed report should be immediately made for the MIA on any organization or phenomenon 'especially clandestine agitations, among agricultural workers' which can be considered as danger to state security and nationally."

${ }^{27}$ National Archives of Hungary Pm. res. 1922-135. in: Papers for the history of the counter-revolution [81: 163-165.]. 
The implementation of this decree also resulted in deeply ideologically motivated police measures, for example, to prevent communist propaganda on cruise ships: [57: 215] "It happened several times during the last shipping season - noted Aladár Györffy, chief police officer in 1937 - that on the pleasure boats chartered by some worker's associations, the participants sang the communist march and some were agitated against the existing social order. In order to prevent these incidents, the cruise ships were supervised and ordered by the shipping companies to notify the Royal Hungarian Ferry Headquarter at least 24 h before departure of the chartering of each passenger ship, with the name of the charterer, the place and date of departure and arrival and the place of travel. Then the Ferry Headquarter is required to notify the Political Investigation Department of the Metropolitan Police, which will arrange for proper inspection of the ship.

During the years of war, there was a perceptible increase in the fight by the secret services against the left-communist enemy, while the growing right-wing factions were only followed by the steady right winging of state-government actors and armed forces. In early 1943, the Minister of the Interior Ferenc Keresztes-Fischer held a narrower meeting, the only object of which was defence against Bolshevism. László Ferenczy, later director of the Jewish deportations of the summer of 1944, was present at the meeting as one of the leaders of the Metropolitan Central Investigation Command. In his lawsuit in 1945, he confessed the following: "Deputy Chief József Sombor, Major Ujszászy, and Gendarmerie Colonel Kudar were present. The leaders of the defensive and offensive wings of the Chief of Staff. I remember the name of Gyula V. Kádár, but no other. Head of the National Defence Department of the MoD, Gendarmerie Lieutenant Colonel József Czigány, the commander of the gendarmerie detective headquarters, me as an instructor and colonel József Babos, judge of the military tribunal. The Interior Minister outlined the Bolshevist threat and ordered a more effective defence. For both the police and the gendarmerie leader of the Bolshevist investigations, Major Ujszászy - the leader of the State Protection Centre - appointed and ordered a meeting every two weeks, under the leadership of itself. At these meetings, Ujszászy presented communist and partisan investigations in progress in various parts of the country; In Transylvania, Zakarpattia Oblast, Bačka and Prekmurje. The basis for the investigation launched in the spring of 1943 in and around Budapest was the propagation of pamphlet in the autumn, winter and early 1943."28

The legal bases for the political-in fact "communist" - crimes of the period were published in the Act III of April 6, 1921, which was about stronger protection of the state and social order. The so-called "Act of Order", which also included guidelines for the powers of the secret services, did not include communist or socialist expressions, it was however, apparently created to prevent the repetition of the recurrence of the Hungarian Soviet Republic at any time. The act's proposal only indirectly refers to the main motive of the legislation: "The sad events of the aftermath of the

\footnotetext{
28 Interrogation of László Ferenczy at the Political and Law Enforcement Department of the Budapest Police Headquarters on November 9, 1945. Hungarian State Security Authority 3.1.9. V-79348, in: 52: 102.
} 
war have proven that we must have laws that are capable of repelling elements that have been misled by the subversive ideas of our time. We have seen the disruption of the legal order shake the pillars of state and social life, pushes all existing state and social systems in devastation and threaten the lives and wealth of the society built on them." 29

According to József Tasnádi Kovács, National Assembly spokesman, ${ }^{30}$ the bill of Justice Minister Vilmos Pál Tomcsányi had not included in the text expressis verbis, that it wanted to be a defensive legislation against anarchism, Bolshevism and nihilism, because these technical terms can be difficult to define using legal terminology. Later he argued in favour of passing the bill: "Let us create this law, create all such laws. I believe that we will truly serve the public liberty, the interests of the Hungarian race, and the order of the country if the wounds of the so-called liberal Jewish era, the war, the turmoil of the Károlyi-revolt, the mess, the robberies, the degenerate social democrat thinking and activities that the communist Jewish Soviets have struck are being healed by institutions that are after all capable of permanently healing the order of the country." (164th session of the National Assembly March 12, 1921. Documents of National Assembly, 1920. VIII. Vol. 17, February 1921—March 14, Budapest, 1921. [56:551])

A similar argument was also expressed by Béla Túri in the case of the Christian National Union Party's openly anti-communist character: "We are actually a mass movement, we must say that we want to defend against what happened because it is nothing more than the proletarian revolution and dictatorship itself; but we want to defend ourselves in advance so that it does not happen. We have seen what Bolshevism is; that it is actually the destruction of all civilization, that it is only liberating the raw masses by the human passions, the most brutal force. I also see that through the windows, which had opened by liberalism, only Galicians came in. [81:343]

Despite the debates over the three quarters of the year since the bill was tabled, it was finally adopted by the National Assembly on March 14, 1921, leaving the wording of the most criticized Paragraph No. 1 in unchanged form: "In order to subvert or destroy violently the legal order of the State and society, anyone who initiates or directs a movement or organization, in particular the establishment of the violent rule of an exclusive social class, commits a crime and is punishable by up to five years imprisonment."

Anyone who actively participates in such a movement or organization, or who promotes such a movement or organization, commits an offense and is punishable by imprisonment of up to 3 years.

If they had previously learned about it or if they could have foreseen with proper insight, obtaining higher amounts of weapons, ammunition, explosives or other lifethreatening substances or materials for the movement or organization, the initiators and leaders will be punished from ten to fifteen years in prison, and other participants and promoters will be punished by up to five years in prison."

\footnotetext{
${ }^{29}$ No. III Explanatory Memorandum of 1921 on the Stronger Protection of the State and Social Order. Documents of National Assembly 1920/22. IV. vol. No. 125. 307. p.

30 József Tasnádi Kovács, a representative of a Hungarian village, Hajdúböszörmény. [93].
} 
Anyway, Act VII of 1946 entitled "Protection of the Democratic Order and the Criminal Law of the Republic", which came into force on March 23, 1946, did not miss the opportunity to criticize features of the "Act of Order". "The criminal laws to protect the Hungarian state, as laid down in the Criminal Code and its subsidiary laws - in particular Act III of 1921 - are insufficient to protect the democratic state system, are largely inadequate, and can therefore no longer be maintained. With the dissolution of the kingdom's institution, the Criminal Code's chapter on lese majesty has largely expired and is not structurally appropriate; due to recent developments the Act doesn't satisfactorily handle the recent political crimes. Besides there are also irrefutable arguments against the continued application of the Act III of 1921, which as an Act - besides that it conserves the state and social order of the counter-revolutionary era by widespread criminal law protection - aims directly to oppress the left-wing labour movements and free expression of political opinion under the terms of the "subversive movement' and 'national libel'." (Act VII of 1946 on Criminal Protection of the Democratic State and Republic. No. 3 of the National Law Gazette of 1946, March 23, 1946. In: [83: 93.)

Paradoxically, the application of the provisions of Act VII of 1946 in order to provide more effective protection of the state and social order would have been less necessary because of left-wing or civilian-opposition organizations, but rather the factual elements of the law adopted 25 years earlier. Because of the significant "focus point repositioning" toward the left-wing politics and the political police, it was almost predictable that the government with time would be infiltrated and overthrown by (far) right-wing elements. [101: 234]

The Sztójay-government, which governed between March and August 1944, under the German occupation of Hungary, within the political police established a new investigative body called The State Security Police. After the Arrow Cross coup, the national leader Ferenc Szálasi did not dismantle the existing apparatus and even created an additional body within the MIA under the designation of Subdivision VII/d, ${ }^{31}$ known as the National Impeach Organization. However, there was another establishment, with almost the same name called National Impeach Office; this was a special tribunal led by the Arrow Cross Party and tasked to examining the role of former governments. [27: 401] Moreover, in this period, another unit called The National Impeach Detachment also existed, it was created in late November 1944, and its main tasks were only later specified. Among the main objectives, this unit supervised the phenomena, which directly threatened the attainment of the objectives of Hungarist-ideology and assisted in the detection of anti-state and anticommunity crimes. Its members, the "impeachers" paid special attention to search and hunt down Jews, deserters, military and civilian refugees, partisans and their relatives. (National Archives of Hungary. K-775. 1/231. In: [39: 85.)

The credibility and contradictions of the statements made in the course of political litigation serve well to illustrate the evidence of Géza Lakatos-the last prime minister in the Horthy era-in "Tribunal of the General, attached to the Hungarian Royal Minister without Portfolio, responsible for the total mobilization and

${ }^{31}$ Confession of Gábor Vajna. Hungarian State Security Authority 3.1.9. V-146147. 
combat-readiness of the nation", which was recorded in the Sopronkóhida prison ${ }^{32}$ : "The investigating authority, for example, expected him to answer what the government, his government did against the truce plans which - according to the Impeachers - was equivalent with the crime of capital treason." Lakatos said, among other things: "On 12th October, I once again summoned the German envoy to restore the supposedly shaken confidence between the two countries, saying that I am prepare to take all the measures and actions he suggests, and I said that only, because I wanted to obtain the further support of him and the armed forces." 33 When he was heard at the trial of Szálasi in February 1946 by The People's Court, he was confronted then with the fact that the records of confessions-which he had made previously to defend himself during the Arrow Cross era-were now intended to be abused by the People's Court. At the same time he writes the following in his memoirs: "The audience applauded when I declared that no Jew had been deported from Budapest during my time as Prime Minister. The people in the courtroom screamed in chorus: » We know, we know! «. [41: 218]

The official bureaucratic, but also Christian-conservative ideological values have changed radically compared to the internal secret service language when the political language of the Arrow Cross Party has become a state language. The development of the style of the far right-wing was influenced by political anti-Semitism of post-Austro-Hungarian Compromise of 1867 as well as the literary and journalistic style of the continuous radicalizing right-wing after the First World War and the fall of the Soviet Republic. At the same time, Ferenc Szálasi was not simply satisfied with the "already-established" rhetoric of the far-right, but he himself developed this despite his own neologist practice. In all of these changes, there are visibly strong parallels with the development of the Nazi language: "The Third Reich had created only a few words in its own language, perhaps, indeed, none. The Nazi language refers to the foreign world in many ways, and takes many other words from the preHitler German language. But now it changes the word value and word frequency, makes this language a common property that used to be the property of some of a small elite before, seizes them for the party while infusing words, phrases and sentence forms with its own poison, puts the language into its formidable system and creating the strongest, most obvious, and most secret means of propaganda within it." [36: 19-20]

The mysterious, peculiar importance of the word "blood" indicates similar importance in the Nazi and Arrow Cross dictionary. "At ceremonial moments, of course, the blood must manifest itself in a positive or negative way. When»even Goethe felt invulnerable humiliation «before Napoleon, he was»silenced by the word of blood «; when the Dollfuss government turned against the Austrian National Socialists, then»against the word of blood «; and when Hitler's troops marched into

\footnotetext{
32 The fate of Géza Lakatos after October 16, 1944 could be considered as "usual": detention of the Arrow Cross Party, interrogations, then Soviet internment; questionings as witness in war crimes trials; retirement, average work, and modest monthly wages to provide the most livelihood. [41: 319-331].

33 Record of the hearings of the former Prime Minister Géza Lakatos on the criminal case against Lajos Veress and his associates. Sopronkőhida, 12 February, 1945. In 83: 113.
} 
Austria,» the hour of blood had finally come «.” [41: 262] When Szálasi acted like a neologist in the political language and created his own specific and individual vocabulary - "clot reality", "blood reality", and "race sibling" and so on.- and who, in his political speeches, uses sharp sentences to cut complicated circulars-imitating Mussolini-sometimes spoke still colorfully without using his own vocabulary.

According to his diary entry of October 20, 1943: "They keep saying, the end justifies the means. Aside from being misquoted ${ }^{34}$ — because it is not any kind of end that justifies the means - let's leave in full the fake abbreviated form of this phrasealso falsified by the liberal-plutocratic-Marxist system-but then don't be surprised by those who use this phrase in a way to attain such an end for which the means are justified; if, therefore, their means are iniquity, infidelity, disbelief, lies, then the end must be commensurate, that is, that which can be achieved only by these. Therefore, do not be surprised if peoples, even their own peoples, will do not accept this kind of end, because none of the nations have the weapon of iniquity, infidelity, disbelief and lies — only the Jews, who will this end never achieve." [31:69]

Szálasi also attributed strong symbolic importance to language use measures such as abolishing the use of titles of feudal origin (lord, sublime, esquire etc.) ${ }^{35}$ in addition, abolishing the term "gentleman", which was replaced by the term "brother" by the Hungarists. [62: 167]

An excerpt from Ferenc Szálasi's speech on January 8, 1944, before the Legislature called the National Federation, who had fled from the Soviets toward west, he states: "Nor can I refrain from thanking the Hungarian representatives of the Plutocratic Marxist-Pseudo-Nationalist Socialist Association for confirming and justifying our fundamental claim last year that we are either being destroying or being destroyed. In particular, we would like to also thank them for proving clearer than the noonday, that in this war, it is not necessary to defeat an honest enemy, but to trample a dishonest maggot." [30: 195]

For the remaining Western part of Hungary, Szálasi also redefined his security policy "creed": "No one shall sabotage the great struggle of our nation, because anyone who does not work for it will die. Every effort must be made to tirelessly, day and night, in the success of the retaliation and in the reconstruction of the liberalized country. Particular care must be taken when carrying out spring agricultural work. This rest of the country will have to supply the completely liberalized country. Not a single foot of land can remain uncultivated in this country. We do not tolerate a derelict land. We will eliminate the knaves of our nation, wherever they are and, at the time of a great travails of our country, who are acting detrimentally to our nation. We will not feed parasites and rogues from the bread created by the sweaty work of the Hungarian people. We give everything to the army to achieve the final victory. But we are ruthlessly killing anyone who obstructs the final victory in any way."36

\footnotetext{
34 For the better understand: Szálasi does not refer to himself, but to Machiavelli.

35 The same decisions were made earlier by the Soviet Republic and later also by the Provisional National Government, in 1945.

36 Cohesiveness (newspaper of the extreme right Arrow Cross movement) January 14, 1945.
} 
According to his diary entry of December 2, 1945, written in prison: "I want to be the conscience and loud cry of my nation, and remain in this 'Hell of Babellike' chaos of political, economic and social, worldview, ideological and regime change. And hungarism is a burning torch, a lighthouse, which means a clear purpose, a secure path and a trustworthy base for anyone who dares and knows to choose it instead of 'gambling' with the homeland." [31: 535]

Meanwhile, the regulations of the secret services continued to be in the traditional language, apparently in view of the constant and ongoing need for a clear interpretation of the norms. On November 27, 1944, the decree issued by Jenó Szöllősi, as Deputy Prime Minister to Szálasi, on the extension and promulgation of a new martial law, utilizes the usual phrases of the traditional juridical bureaucracy: "Under the authorization of Paragraph No. 221 of Act II of 1939 on National Defence, the Royal Hungarian Ministry extends the martial law beyond the criminal offenses under existing law-to cover both the civilian and the military criminal areas throughout the country and in the military criminal justice system itself. For further notice concerning the new extension of martial law in the civilian criminal jurisdiction and in further proceedings, see the provisions of 8.020/1939. M.E. and 7.800/1941 M.E. decrees and based on the promulgation of the martial law in the criminal procedures concerning the personnel of Defence Forces (Paragraph No. 437 of Act XXXIII of 1912) and in the further proceedings, the provisions of the relevant military prosecution code of Chapter XXVI. Incorporated into Act XXXIII of 1912 and the provisions of 1.420/1944. of M.E. (Hsbp.) decree shall prevail." [32: 36]

László Karsai, Hungarian historian and researcher of the Holocaust, in one of his scientific article mentioned that Szálasi was warned several times by his immediate colleagues that his texts could not be understood by the broader audience (while Hitler could be understood). Once Szálasi gave the following answer to his colleague concerning the problem of misunderstanding: "That is not a problem, if they don't understand me, the important thing is to believe in me." [31: 102]

One can only think - ponders László Lengyel, a Hungarian economist and political scientist - that, what a deeper impact would it have on the Hungarian language if the National Consolidation Government had lasted longer, how would it have integrated into the everyday vocabulary and how the language-models «of the Third Reich and the Fascist Italy would have influenced the Hungarist fascist language? How would we have learned the leader's dream in our schools, how would be the fourth reading in our textbook could have been the leader's childhood and happy family life with the title»Beloved Family «? And how would we have learned these thoughts as a life principles «because they would keep us educated from a very young age to death." [43: 10]

The validity of László Lengyel's ideas can also be seen-mutatis mutandis-in relation to the language that was rapidly becoming 'Stalinized' after the war: "What a deeper impact would it have on the Hungarian language if the proletarian dictatorship had lasted longer, how would it have integrated into the everyday vocabulary and how the language-model of the Soviet Empire would have influenced the Hungarian language?" 


\section{The Period of the One-Party System (1949-1989)}

The Second World War was definitely a fundamental milestone in this research topic, the conditions of the research of documents concerning the language of the secret services had changed significantly since then. Namely, Act XXIII of 1994 on The Supervision of Certain Persons Occupying Important Positions, amended in 1996, handed over the documents of the communist secret services to the care and conservation of the Historical Office. ${ }^{37}$ Therefore, ideal institutional conditions were created for the continuous and systematic receipt, handling and storage of the documents, which were later also supplemented with the declassified documents of the other secret service branches. Such a need and opportunity cannot be availed of in the case of documents of the secret services before 1945 due to the passage of time, but even more so due to the unknown location and fate of these documents.

Therefore, the most important parameters of the systematic research of technical language indicators mentioned in the hypotheses-the internal commands, the preparatory interviews with the recruitment candidate, the handwritten agent reports, the confessions and records of interrogations, the propaganda texts addressed to the public, created by the secret services, or the texts of operational information intended to mislead the enemy/opposing party — can only be the subject of more extensive investigation during the period of the One-Party System.

In 1945, a breakthrough in the country's history completely transformed and changed the institutional framework of the secret services. The establishment or dissolution of certain civilian and military state protection organizations was largely determined by the country's major political forces, but even more so by directives from Moscow. The struggle for control to the victory of the Soviet-backed Hungarian Communist Party (later the Hungarian Workers' Party), thus securing a decisive role for the secret services in shaping the domestic affairs of the coming decades. In accordance with the expectations of the Allied Powers, the prosecution of war criminals was also a priority in the Hungarian political and military sphere, as reflected in the preliminary ceasefire agreement signed in Moscow on January 20, 1945.

At the end of the transitional period, the State Protection Department of the Hungarian State Police was established in the autumn of 1946, a year later it continued to function as the State Security Authority of the MIA. The State Security Authority, now under the guidance of the Ministry, which was directly subordinated to the Council of Ministers, was established at the end of 1949 This authority incorporated

\footnotetext{
37 Organizations, which documents referred to be served by law: MIA State-Security General Directorate III/III Department, the subdivisions of MIA III/III in the districts of Budapest or county police headquarters and their predecessors (the Political Investigation Department of the Hungarian State Police, the State Protection Department of the Hungarian State Police, the State Security Authority of the MIA, the State Security Authority of the People's Republic of Hungary, and all their counter-internal reaction departments, MIA Department IV for Counter-Internal Reaction, MIA Political Investigation Department V for Counter-Internal Reaction, the former MIA Departments of Internal Security, Foreign Affairs and International Relations, the former Border Patrol Reconnaissance Unit of MIA, and other self-produced documents of the former State Security Operations Registry. Paragraph No. 2 of Act LXVII of 1996 on the amendment of XXIII of 1994 on The Supervision of Certain Persons Occupying Important Positions. Markó, Gy. [48: 19].
} 
military intelligence and counter-intelligence as well as the border guard. The classic secret service structure of the toughest years of the Rákosi era lasted until the beginning of the "new phase" policy marked by Imre Nagy, when the State Security Authority was re-merged with the MIA. [65: 211-237]

Instead of the State Security Authority, dismantled by Imre Nagy during the Hungarian Revolution of 1956, to carry out the state security activities, the (Political Investigator) Department II of the MIA was established. This Department operated between 1956 and 1962 and played a key role in the retaliations at the beginning of the Kádár era, directly following the revolution. After the reorganization of the MIA in the first half of the 1960's, a new structure of state security institutions was created in 1962-1964, which was operational until the change of regime. In this emerging new state security structure, based on the model of the military organizing principle, the various tasks and branches were organized into general directorates. [10: 73-90] The changes in certain phases of the era did not affect the model of dual subordination of the secret services: internally, the political power and the decisive role was exercised by the Hungarian Workers' Party through the party apparatus. Externally the will of the Communist Party of the Soviet Union had prevailed, which was interpreted positively by the soviet secret service. Because of the Sovietization of society as a whole, the form and substance of ideological content were directly reflected in the language of the secret services.

Miklós Szabó, a Hungarian historian, calls the language of the pre-1945 period a "mythical" language: "Originally, the mythical language expresses political substance in the credentials of some religion (typically Christian) and in the visuals and symbols depicting them. The noble ruling classes in Hungary expressed their political worldview in nationalist » historical mythology «, which phenomenon can be understood as a secularized religion." After 1945, however, the role of religious mythology was taken over by the simplified or even diminished version in the form of "linear-structured language" of Marxism used in Soviet-type systems, and thus made it a mandatory political state language. [84: 24]

Changes in the language and vocabulary of the era were to a large extent related to production, political-movements, world politics and "booming" in cultural life: planned economy, people's economy, labour competition, competition committee, labour offering, brigade movement, Stakhanovite movement, shock workers, shock labour teams, council(s), council member(s), executive committee; party activism, revision, class loyalty, cadre, party cadre, party mandate, party session, class enemy, class struggle, peace struggle, peace camp, peace front, peace policy; cultural program, cultural team, cultural guard, cultural assets, aggressor, kulaks, soviet, bourgeois, collectivize, etc. [22: 25, 12: 191-198]

In a peculiarly symbolic form, the Supreme Court vice president expressed that the judiciary was also seeking guidance from the Soviet Union: "In this courtroom, the judges of the old Curia had been sworn in for decades. Since then, even the image of the courtroom has changed. The chairs are now placed in equal rows, thus giving the expression equality before the law. Before liberation, the rows of chairs were staggered, symbolizing that the Curia was the court of the privileged classes above the people, where the affairs of the members of the people could only rarely appear. At that time, the chairs were facing west, which symbolized that the old 
judges applied the almost literally translated laws from Germany in a foreign spirit. Now, the picture of the courtroom is facing north, toward the country, the Soviet Union, thanks to its victorious army that today we can swear an oath to the Constitution of the People's Republic. This change symbolizes the fact that our legal system is turning to the Soviet Union for guidance, because now we also build the socialism." (Records of the full session of the Supreme Court of the Hungarian People's Republic. Budapest, 18 November, 1949. In: 83: 307)

One of the language-critical researches of the "new period" of Imre Nagy, besides linguistic Sovietization, drew attention to further linguistic-political dysfunction: "We cannot understand the nature and essence of political jargon, if we see linguistic errors originating from the uncivilization of it and we will not even understand it in those cases, when we ignore the fact, that these jargons had "flourished" during the dictatorship of the proletariat, at the time of the Cultural Revolution. [19: 63]

In this period, in the case of the secret services the 'language-imitation' was the predominant style of public speaking for propaganda purposes. From 1937 until the dissolution of the Komintern in 1943, Mihály Farkas worked again in the Moscow apparatus of the Communist International, and from 1945, as Communist Party Under Secretary of Home Affairs answerable to Rákosi, he also supervised the police, secret services and the army for many years. While preparing a lawsuit brought against László Rajk, Farkas criticized the Titoist Yugoslavia in a fulminant speech. This speech turned out to be a (bad)translation of an article of the communists of the soviet Pravda newspaper: "Tito's fractionists no longer claim that the Communist (Bolshevik) Party of the Soviet Union is »degenerating «, but they are going even much further. Today, they are claiming openly that the Central Command of the Communist (Bolshevik) Party of the Soviet Union and other communist parties are occupied by imperialist agents around the world, but such a wicked statement can only be raised by those who themselves are agents of the imperialists and are working on the disarmament and destruction of unity of the communist world. (Legacy documents of Farkas Mihály and Farkas Vladimir. Archives of Manuscripts of the National Széchényi Library, 429. f. 63-71. fol.)

However, in December 1949, in a similar style and enthusiasm-and in almost the same words -the State Security Authority was greeted by the then Minister of Justice, Ferenc Nezvál, in the parliamentary budget debate ${ }^{38}$ : "Honourable parliament! Last, but not least, I left the role and importance of the State Security Authority. I cannot conceal that our people noted it shockingly, that the imperialist spy ring has infiltrated our state apparatus and people's economy. The imperialists organized a gang of murderers and spies in our country to destroy our state order and our economy. The war inciters and arsonists do not like our peaceful development. That is why Tito's despicable hordes sent spies and saboteurs to our country. They appointed just the MIA to be infiltrated into the most important state body. Many people do not even know how great a danger has fended off with the making of Rajk and his gang harmless. Thanks to the Hungarian Workers' Party and our beloved

\footnotetext{
38 In the parliamentary term of 1949-1953, the State Security Authority was only discussed in the debate on the adoption of the annual budget law.
} 
Comrade Rákosi (Long-time, enthusiastic, steady applause), we succeeded in eliminating this great threat to our peaceful construction work and our entire social order. We are highly commended by our State Security Authority for the brilliant work he has done to hunt down and render harmless the spy ring." (Parliamentary Diary, 1949. Vol. I, Session day 8 June, 8 June, Budapest, 1949. 499. p.)

The importance of the establishment of the State Security Authority on December 29, 1949 was praised by the central newspaper of the Communist Party as follows:

"Horthy-detectives were enemies of the struggle for the liberation of the people. They stood in the mercenary of capitalist gentlemen and landowners and preserved their privileges. Like hounds, they attacked those who raised their hands on the exploitation system, who wanted the factory to belong to the worker, the land to the working peasant. Thus, primarily, the Communists were persecuted, the best and most conscious sons of the Hungarian people. Only the bottom of society, an animalized and dehumanized person could have been a Horthy-detective.

Our political investigators, the staff of the State Security Authority, are coming out from the best of the Hungarian people. Their task is to protect the working people, the state of the people, the achievements of democracy, and peace against the imperialists, the capitalists, the landowners, the kulaks and the enemies and pests of all ranks and rankings, who have lost their power in our state. The employees and investigators of the State Security Authority came from the people; they wholeheartedly love the working people, the cause of socialism, and their homeland. They train themselves in all their spare time to become better able to serve our People's Republic. The Party teaches them, they lead their struggle, and the example of the Soviet state warrior defenders inspires them in their hard, responsible work. Most of them are communist. They are fighting with the Party, the vanguard of the working class, together. They are part of our working class; thousands of threads join them. The five-pointed star on their cap also symbolizes this. [...] This is a source of prestige of the State Security Authority. The unstoppable and untiring work it has done and is doing for the workers, gives prestige for it over the people. With the speed, the security, which it strikes to the pests, creates fear among the ranks of the enemy. We can also say what comrade Dzerzhinsky said on the fifth anniversary of the USSR: 'He guarded the revolution and honoured the difficult task assigned to him." (Our sharp weapon - the State Security Authority. Szabad Nép (daily newspaper of Communist Party), 20 January, 1950. 3. p.)

Almost 1 year later, following the (formal) dissolution of the State Security Authority in 1956, János Kádár welcomed the 'old-new' state security systemthe Department of Political Investigation - to the national session of the Hungarian Workers' Party, held in June 1957. The announced transformation of the secret services was less followed by any "linguistic reform". The caption "The State Security Authority is the First of the Working Class" was a permanent banner/slogan at the political events of the Rákosi period. Kádár could not get rid of this phase either: "From the point of view of power, it is very important to strengthen the and nurture the comradely spirit and unity of the various units of the armed forces towards each other. The state security organ must be the fist of the proletarian dictatorship. In addition, state security organs must be supported by the party and by the people. Their work for the people will be made easier if 
they feel the love and support of the people." (National meeting of the Hungarian Socialist Workers' Party. Népszabadság, (daily newspaper of Communist Party), 30 June, 1957. 2. p.)

Even the documents, created for internal use of the secret services, with the pathetic presentation of the secret services to the public had lasted throughout the Kádár period. Often, simpler internal norms had been preceded by introductions with a strong political nature, such as the pre-legislative preambles. For example, in the Ratkó era, the, unexpectedly less efficient, provisions concerning foecited, were sharply criticized by way of the stricter regulations laid out by the Ministry of Justice. This was addressed particularly to the individuals involved in the criminal processes. Before they got into specific provisions extensive moralizing guidance was drafted:

"In our social development, the organization of health protection has become increasingly important and the fight against foeticide is playing an increasingly important role in this. It has been one of the most neglected areas of our judicial work to date. Together with other bodies, the judiciary has until recently apologized for this sinful activity, which shows that they are unaware of the importance of the issue and so often take the wrong view. It must be clearly seen that abortus is not a private matter, but a matter for the whole people, a serious crime against our working people, our future, but it also endangers the health of individual women and the happiness of our families. A characteristic manifestation of bourgeois moral anarchy and incompatible with our people's democratic system." (Regulation of criminal procedure in foeticide cases. Gyula Décsi Minister of Justice, December 12, 1952. In: 79: 126)

Erik Molnár, Minister of Justice, also sent to the courts an almost 'editorial matching' instruction regarding the case law of wage fraud and level of supply falsification: "The successes of the peace camp, our order, and our people's economy prompt the right-wing social democrats and the clerical reaction to step up their destructive activities without a selection of instruments. One of the most important areas of their attack is the front of production. Through their undercover agents, by misleading some less self-conscious workers, they arrange their sinful business to curb growth, disrupt, hinder our development, and obstruct our peaceful construction work." (Instructions of the Department of Justice to adjudicate on wage fraud and level of supply falsification cases. Budapest, August 26, 1950. In: 71: 322)

The greatest concern with regard to the authenticity of state security documents is the evaluation of agent reports. Depending on their substance, these documents revealed: how well the political officers knew their agents and observed persons, how they grouped the facts contained in the reports, in some cases what they added to the recorded information, what they had taken into account or failed to take into account, how they defined their further tasks, how they set their expectations, and how much they enforced their leadership role. These reports also reveal the personality of agents: does he take the initiative, to what extent does he take advantage of opportunities, whether he is a servant, how willing he is to perform the duties assigned to him, or conversely, how he tries to avoid them-perhaps he shares his own ideas with his case officer. "The substance of the reports may have been influenced primarily by expectations, but the 'agent's pen may have been driven by the 
goodwill of the observed persons and his commentary tried to take the weight of his own words." [64: 145]

Thus, behind the collection of agent reports and file records stands the professional secret agent of all time, who, as a mediator, transmits to the superior bodies information reported (or written) by the agent. It is in his fundamental interest that his reports meet the expectations of his superiors, if he desires to accelerate his career within the organization. To this end, he tries to optimize the information received within the limits of his capabilities. It can also play a part in his conformism: it is "inconvenient" for a professional secret agent to report information that has a negative impact on a government's politics or on leading political personalities. [16: 39] At the same time, organizational efficiency requires that agent reports, secret service evaluations, investigative, prosecutorial and court records consistently bring toa common ground the intentions of the various organs in essentially the same direction and to the same end.

All these, of course, make up part of the substance of the authenticity of the documents. Compared to this, the 'formal' page represented by the language seems secondary. "The voice of agent is almost exclusively expressed in documents (recruit materials and network agent reports) related to their specific network operations." [91: 10] Although this is the starting point, in reality, the voice of the agent is getting quieter as the record progress and finally it falls silent. Namely, in this process, the individual is inevitably depersonalizing the character of the agent and is rendering it a dehumanised albeit factual document. Every individual attribute of his personality is objectified into the data.

This process is of particular importance, when the secret service does not severely simplify the multitude of facts received for pragmatic reasons, but in order to achieve well-considered and expected power goals. In the case of conceptual or constructed proceedings, the result (the judgment) is formed sooner than the path (the proceedings) to it. As Pelikán damper remarked: "Sorry, Comrade Virág, this is my judgment, not a confession!"39

In the retrial of Gábor Péter, a former state security lieutenant general sentenced to life imprisonment in 1953, the Prosecutor General's Office documented the true stories of the falsified confessions made during the Rákosi era's show trials: "In various political lawsuits investigated by former State Security Authority in 1949/52, 29 people were sentenced to death (A checklist compiled in 1951 summed up the number of political prisoners executed from February 1945 to February 10, 1949 by 159 In: 70: 196-200) and 95 people have been sentenced to more than 5 years in prison. During the retrials in the interest of the convicts, it was found that the detainees of the political trials in favour to extort enforced, false testimonies, were forced by the investigating officers of the SSA, under the direction of their superiors, by using the most inhumane mortification, brutal physical and psychological coercion, and convincing persuasion, in order to admit the detainees to confess on their commitment in serious political crimes that in fact have not been committed by them and also to

\footnotetext{
39 Péter Bacsó's film satire "The Witness", made in 1969 but banned for a long time, is one of the most popular Hungarian cult film on communist dictatorship.
} 
confirm these false testimonies during their trials." (The Prosecutor General's Office proposal on the retrial of the case of Gábor Péter and his eight associates. Budapest, May 10, 1957. In 71: 438)

For example, Anna Kéthly, a social democrat politician, was arrested on June 9, 1950, and released on November 19, 1954. She said, in early 1956, during her review process: "After being taken into custody, I was taken to Andrássy Avenue 60. and placed in cell 17. That evening, they put me in for questioning. A major interrogated me, shouting at me in the harshest voice and demanding that I admit that the so-called Committee 6 was leading an organization to overthrow the popular democratic state. I did not acknowledge this, and my interrogator threatened to get one of my sisters captured and beat in front of me until I admit the accusations. As a result, I have signed everything that they had put in front of me. I would like to confess that coercion was used against me during the investigation and that is why I signed all the false, inaccurate records. I signed the records without reading them, they had been written by my interrogator. On the one hand, he wrote lies, and on the other, he distorted the facts. Occasionally, when I was reluctant to sign fake records, I was punished. For example, I could not sleep for 5 days, not wash for a week, etc. For what I could no longer stand these coercions and therefore signed the records in front of me without knowing their substances. During the trial, I could not speak to my counsel, and as I recall, my own forced records were used as a document against me. So those records, which substances were completely fake, my interrogator constructed them." (Records of the interrogations of Anna Kéthly in the Investigation Department of the MIA. Budapest, 3 April, 1956. In: 83: 761-763).

Anna Kéthly's records from her interrogation in the 1950s, were thus unlawful in form and substance. However, she began her 1956 interrogation by saying: "Please, I am now ready to make truthful testimonies about my activities." This was the second year since 1953 that Prime Minister Imre Nagy had initiated the revision of unlawful proceedings. Despite the fact that Social Democratic related affairs were at the end of the list, Anna Kéthly could reasonably have hoped that a possible lawsuit would have had a positive outcome. She did not think of herself at all, she did not apply for are trial of her own case: "However, since my case is closely linked to and related to others, I am, of course, now willing to testify truthfully." [83: 761]

Based on the sincere confession she made, the records could be regarded as substantively authentic. It confirms the assumption that this was not a typewritten, substantiated protocol. Thus, the confession was made in the Investigation Department of the MIA where the record-taking activity by typewriter was not immediately available, and the remaining copy was not retrospectively edited, rather it was kept presumably in its original handwritten form in the archives. After reading these fifteen pages, it is most likely that the rapporteur, in statu nascendi, recorded what was said in the natural context of the oral communication.

At the same time, self-written testimony can, of course, be substantially different from the actual situation and the real opinion. In a Hungarian-American Oil Company show trial, for example, Chief Executive Officer Simon Papp, sentenced to life imprisonment, allegedly emphasized his repentance in his autobiography attached to his later submitted mercy plea concerning the frame-up that occurred 6 years earlier. It seems natural, that in his mercy plea, for his release, he did not emphasize 
his innocence and the conceptual nature of his lawsuit-even if that was the truth. He writes: "I am very sorry and deeply regret, that I have lost sight of the interests of the country, and thus of my own interests. As early as 1948, I acknowledged my crimes and mistakes at my police interrogation and trial at the People's Court of First Instance, and I deeply regretted them. My punishment has further strengthened my repentance." [83: 375]

Just like legislation and investigations of the secret services, the justifications for political judgments paid much attention to adequately articulating the substance of ideology in order to deter the enemy and increase the education and awareness of the workers. [70: 143] The reasoning of 32-page Rajk trial can be considered as the archetype of show trials and of falsified and coerced confessions. Council Leader Judge Péter Jankó also noted that the machination of the accused in the field of women's equality also draws the attention of the international and domestic public: "László Rajk, Lazar Brankov, dr. Tibor Szőnyi, András Szalai and Pál Justus were consciously involved and facilitators of the common-purpose organization of imperialist forces around the world, which is aimed at obstructing the efforts of the progressive powers of the World, destroying their achievements and preparing for a new war. The accused were directly cooperating with the current antipopular Yugoslav fascist terrorist, the Tito-clique, the commando of imperialist war instigators. This conspiracy as a whole, through the accused - according to the sincere confession of the accused - and with certainty as to the facts, whether in the open or in a covert form, offensively aimed the threatened with the destruction of the achievements of human progress, the democracy and socialism in Hungary, the elimination of feudalism, the socialization of industry and commerce, the equality of women, the creation of a real people's rule, and at the same time prepared a bloody fascist terror against the working people." [67: 253]

In the post-trial of László Rajk the court focused on the details of the historical and political context of post-World War II to the same extent as the judgments: "Hungary was liberated from fascism by the triumphant progress of the Red Army and at the same time as the rebuilding of the country, it began to build the freedom it had longed for but had not achieved. In 1945, right after the liberation, there were various capitalist parties in power alongside the working class, and the struggle between socialist and capitalist forces had not yet been decided. The capitalists and their supporters, the foreign imperialists, wanted to transform Hungary into a bourgeois country and, in pursuit of their goal, sought to return to the state apparatus those who had partly fled in 1944 and were removed by the people at the time of liberation. Thus, a huge struggle has begun within the army and the police to return former fascist officers, while the democratic forces, under the leadership of the Hungarian Communist Party, are rebuilding the country and are focusing their efforts on capitalist reactionary positions. However, imperialists are making plans for the long term, and they are only infiltrating with help of one part of their intriguers in rightwing parties and with the other part they are carefully seeking to infiltrate covertly in left-wing parties, partly in order to make disturbances at their best time and partly through their destructive machinations to hold back the path of development. Last but not least, once all of their agents had exposed by the progressive forces, they will be able to regain their lost power with the help of the other covert persons, who 
have been placed in a key positions by the progressive forces, if it is necessary at the cost of an armed coup. With tenfold energy, with a furious passion and increase a hundredfold in passion and with their exploitative harassment techniques, they are seeking to restore a state that is a paradise for them and for the masses of the people only got poverty as a class share." [83: 255-256]

It is no coincidence that the style, language and vocabulary adopted in these political trials proved to be a suitable model of communication for the retaliations after 1956. As much as the Kádár-system sought namely to keep itself away from the Stalinist power-exercise technique and its way of thinking by proclaiming the "struggle on two fronts", it ultimately maneuvered itself into the same one-sidedness, that we saw previously in the case of the image of the Horthy era's enemy. In fact, proclaiming the symmetrical separation between the two extremities has placed the threat of communist radicalism, - the perceived or real - threat of right-wing revisionism, at the centre of the activities of the secret services.

\section{Conclusions}

As for the peculiarities of the political language - including the secret servicesafter the change of the regime, it can be hypothetically stated that in today's Hungarian political life, political communication, which operates exclusively with the face of enemy, definitely 'outraced' its user in the long run. Therefore, paradoxically, the main enemy image of the "Hungarian ideology" of the three decades after 1990 is the enemy model itself. This is, of course, precisely the ideological settling and counter-reaction of phantomized enemy imagery, which features the real political struggle itself. The new situation requires a new language, which must express the specifics of the new Hungarian political model and, as far as possible, have the ability to be simplified as soon as possible from the language of the political caste into a public language.

Open Access This article is licensed under a Creative Commons Attribution 4.0 International License, which permits use, sharing, adaptation, distribution and reproduction in any medium or format, as long as you give appropriate credit to the original author(s) and the source, provide a link to the Creative Commons licence, and indicate if changes were made. The images or other third party material in this article are included in the article's Creative Commons licence, unless indicated otherwise in a credit line to the material. If material is not included in the article's Creative Commons licence and your intended use is not permitted by statutory regulation or exceeds the permitted use, you will need to obtain permission directly from the copyright holder. To view a copy of this licence, visit http://creativecommons.org/ licenses/by/4.0/.

\section{References}

1. Aradi, Nóra. 1979. Fine Art Life in 1919. The Present, 3.

2. Balogh, József. 1921. Propaganda. In. Gratz, Gusztáv: Bolshevism in Hungary. Budapest.

3. Bauer, Friedrich L. 1997. Decrypted Secrets-Methods and Maxims of Cryptology. Berlin: Springer. 
4. Bertényi, Iván J. R. 2016. Some Characteristics of World War I propaganda in Hungary. In Bertényi, Iván J. R. and Boka, László (eds.). Propaganda in World War I. National Széchényi Library, Budapest.

5. Bizony, László. 1919. 133 Days of Hungarian Bolshevism-The Bloody Reign of Béla Kun and Samuelly. Leipzig-Wien: Waldheim-Eberle.

6. Bok, Sissela. 1983. Lying. Moral Choice in Public and Private Life. Budapest: Vintage.

7. Gábor, Böll. 2001. Organizational History of Directorate of Military Staff-2 in the Light of Recent Research. In Military lawsuits under communist dictatorship, ed. Okváth Imre. Budapest: Historical Office of Budapest.

8. Botos, János. 1995. The History of the Ministry of the Interior from the Fall of the Monarchy to the End of World War II. In Chapters from the History of the Interior Ministry. Budapest.

9. Crystall, D. 1997. Cambridge Encyclopedia of Language, 2nd ed. Cambridge: Cambridge University Press.

10. Cseh, Gergő Bendegúz. 1999. Historical Outline of the Hungarian State Security Organs, 19451990. In Trezor 1, ed. Gyarmati György. Budapest: Historical Office.

11. Cseh, Géza. 2011. Red and White Terror in Szolnok. Rubicon, 2. Budapest.

12. Csige Katalin, P. 1998. Lexical and Semantic Russicisms in the Press Language (1948-1951). In Yearbook of the Department of Hungarian Linguistics, vol. 35, ed. Sebestyén Árpád. Debrecen: Kossuth Lajos University.

13. Csima, János. 1968. Additions to the Horthysta Staff's role in the war policy of the counter-revolutionary system. Journal of Military History. 3. Budapest.

14. Csunderlik, Péter. 2019. From "Red Carnival" to "Red Tartar Invasion" - The Soviet Republic in the Pamphlet and Memoir Literature Early Horthy-era. Budapest.

15. Raphael, Demos. 1960. Lying to Oneself. Journal of Philosophy 57: 588-595.

16. Dezső, Lajos, and Hajas Gábor. 1997. Legislation on National Security Activities. Budapest: A Comment for Practice.

17. Donáth, Regina. 1964. Usage of Diplomatic Cryptography in the XVII. century. Budapest.

18. Farkas, Vladimir. 1990. "There is no excuse". I was a colonel of the State Security Authority. Budapest.

19. Fónagy, Iván and Soltész, Katalin. 1954. About the Movement Language. Budapest.

20. Fóris, Ágota and Bérces, Emese. 2007. Current issues in Musical Terminology and Musical Lexicography. Budapest.

21. Grecsák, Károly and Lányi, Márton. 1919. Hungarian Laws. Articles of 1918 with Indexes of all Current Laws. Budapest.

22. Grétsy, László. 1976. Reflection of Socio-Economic Changes in the Common Language Vocabulary. Budapest: Our Hungarian today.

23. Habermas, Jürgen. 1971. The Structural Transformation of the Public Sphere Budapest.

24. Haraszti, György. 2007. Confessions from the "House of Dead". Memoirs of Major General István Ujszászy, Head of Directorate of Military Staff Unit 2 and the State Protection Center. Historical Archives of the Hungarian State Security-Corvina Kiadó. Budapest.

25. Hevesi, Attila. 2018. Strömpl, Gábor (1865-1945) and the Hungarian Geographic (Earth Science) Terminology. Historia Scientiarum. 1. Budapest.

26. Hewstone, M. and Antaki, Ch. 1995. Explanations of Attribution Theory and Social Behavior. In. Hewstone, M. Stroebe, W., Codol, J. -P. and Stephenson, G. M. Social Psychology - from European Perspective. Budapest.

27. Hollós, Ervin. 1972. Police, Gendarmerie, Directorate of Military Staff-2. Budapest.

28. Horváth, Péter. 2005. The Internet and itsTerminology-by a 'Semi-professional' Eye. Scientific and Technical Information. 5. Budapest.

29. Jakab, István. 1974. For the Systematic and Terminological Questions of Literary Language, Common Language, Dialects. Literary Review 17. Budapest.

30. Karsai, Elek and Karsai, László. 1988. The Szalasi trial. Budapest.

31. Karsai, László. 2016. Diaries of Ferenc Szálasi 1942-1946. Budapest.

32. Karsai, László. 2008. Reflector into the Dark. Ferenc Szálasi’s diary, September 15, 1943-July 18, 1944. Spokesman, 3. Budapest.

33. Kegyes, Erika. 2016. Opportunities for Teaching the Terminology of Logistics in the Light of a New Curriculum, vol. 2. Budapest: Applied Linguistic Publications. 
34. Király, István. 1996. The Secret and its Categorical Structure. Hungarian Review of Philosophy 1986. 1-2. In. Border-Listening-Secret. Cluj-Napoca, 1996. in revised form. In. Border-Listening-Secret. Komp-Press, Cluj-Napoca.

35. Kiss, Balázs. 2006. From Mission to Marketing. Budapest: Media-Research, Spring.

36. Klemperer, Victor. 1984. The Language of the Third Reich. Budapest: Mass Media Research Centre.

37. Konok, Péter. 2010. Issues of Violence 1919-1920. Red Terror-White Terror. Budapest.

38. Kovács, István. 1980. October Decrees and the First Soviet Constitution. Budapest.

39. Kovács, Tamás. 2006. The National Accounting Detachment, vol. 3. Budapest: Our Past.

40. Kovács, Zoltán András. 2009. Ministry of the Interior of the Hungarist Government of Szalasi. Gödöllő: Law Enforcement, State Security, Public Administration.

41. Lakatos, Géza. 1992. "As I Have Seen”. Budapest.

42. Láng, Benedek. 2015. Encryption in Early-Modern Hungary. Budapest.

43. Lengyel, László. 1985. War Criminals-About Themselves. Prison-conversations. Movie Review, 3. Budapest.

44. Machiavelli, Niccoló. 1978. The Prince. Budapest.

45. Malaczkov, Szilvia. 2018. Economy and Terminology. Budapest.

46. Mao, Wenbo. 2004. Modern Cryptography_Theory and Practice. Upper Saddle River: N. J. Prentice Hall.

47. Markó, Árpád. Additions to the History of the Development of the Hungarian Military Language. Journal of Military History. 1958. 1-2. 3-4.; 1959. 1. 2.; 1960. 1. 2.; 1961. 1. 2. Budapest.

48. Markó, György. 1999. Report for the Parliament about the Activities of Historical Office between 1997 and 1998. Budapest: Historical Office.

49. Máté, Judit Eszter. 2012. Metaphoricality of Church Terminology. Teaching Hungarian-Methodological Journal. 4. Budapest.

50. Malaczkov Szilvia. 2018. Economics and Technical Language. Budapest.

51. Mitrokhin, Vasili. 2004. KGB Lexicon. The Soviet Intelligence Officer's Handbook. London: Frank Cass.

52. Molnár, Judit. 2014. Gendarme Officer at Marko. Lieutenant Colonel László Ferenczy before the People's Court. Scolar-Historical Archives of the Hungarian State Security, Budapest.

53. Müller B. Tamás. 2016. Red terror in the Parliament, 1919. Budapest.

54. Murányi, Gábor. 2004. Naming of Agents. Service fondling. In The Texture of the Past-Stories From the Cracked Twentieth Century. Budapest.

55. Nábrádi, Mária. 2007. The Psychology of Lie. Budapest.

56. National Assembly Diary 1920. VIII. Vol. 17, February 1921-March 14, 1921. Budapest.

57. Nemes, Dezsô. 1956. Papers for the History of the Counter-Revolution 1919-1945. Vol. II. Budapest.

58. Nikolov, Elit. 1987. The Secret. The Opposite of Communication. Mass Communication Research Center. Workshop 3. Budapest.

59. Olysói-Gabányi, János. 1923. The Military Language of Hungary. Budapest.

60. Opál, István. 1978. Considering the Ideological and Philosophical Aspects of the US Anti-communist Psychological Warfare After World War II in Perfecting the Method Used by the Professional Service. Candidate Thesis, Historical Archives of the Hungarian State Security. Budapest.

61. Ordinance of Police Criminal Agencies Work. 1964. Historical Archives of the Hungarian State Authority, Budapest.

62. Paksa, Rudolf. 2013. Ferenc Szálasi and Hungarism. Budapest.

63. Pamlényi, Ervin. and Karsai, Elek. 1951. The White Terror. Budapest.

64. Pihurik, Judit. 2011. Undermining of People's Democracy in a Wine Cellar of Szekszárd. Centuries. 1.

65. Pintér, Tamás. 2000. The Eliminated Preserved State Security Authority. In Gyarmati, György (Ed.). State Security in the Rákosi Era. Studies and Documents on the Activities of the Political Police after the Second World War. Budapest.

66. Pléh, Csaba. 1995. Variations. Changes in the Symbol Processing Mind-set and Symbol Concept. In Kapitány, Ágnes és Kapitány, Gábor (Ed.). "Life is a Hidden Speech”. The History and Research Methods of Symbolization. Budapest.

67. Rajk, László and his Associates before the People's Court. 1949. Budapest.

68. Ress, Imre. 2012. Transformation of the Government Intelligence in the Austro-Hungarian Monarchy after the Compromise 1867-1873.). In. Csóka, F. (Ed.). Special Service for National Security of Hungary. Budapest.

69. Révay, Zoltán. 1978. Encryption-Chapters from the History of Encryption. Budapest. 
70. Révész, Béla. 1997. Criminalization of the Ideological Function of the Proletarian Dictatorship. Ideology-Politics-Law in Hungary in the Fifties. Szeged: Szeged University.

71. Béla, Révész. 2016. Documents from the History of the Ministry of Justice 1944-1990. Budapest: Ministry of Justice.

72. Révész, Béla. 1996. Manipulation Techniques in the Early Cold War Period. Szeged: Szeged University.

73. Révész, Béla. 2006. Significance of the "Danube-gate" case in the History of the Change of RegimeAlternatives of Political Interpretations. Szeged: Szeged University.

74. Sándor, Klára. 1999. The paradigm found - or what science history is good for. Hungarian Philosophical Review. 4-5.

75. Sarlós, Béla. 1961. Revolutionary Tribunals of the Soviet Republic, Budapest.

76. Seregy, Lajos. 1985. Usage of Military Terminology and Soldiers' Language. Defense Review. 2.

77. Simmel, Georg. 1973. The Secret and the Secret Society. In Selected Social Theory Studies. Budapest.

78. Simonovits, András. 2003. János Neumann and Game Theory. World of Nature. 3.

79. Singh, Simon. 2001. The Code Book. The Science Science of Secrecy from Ancient Egypt to Quantum Cryptography. Budapest: Anchor.

80. Solymos, Rezsô. 2000. The Role of the Forestry Terminology in the Development of Hungarian Forestry. Hungarian Science. 10. Budapest.

81. Ágnes, Szabó. 1955. Documents for Studying Hungarian Party-history, vol. IV. Budapest: Hungarian Institute of History of Workers' Movement.

82. Spät, András. 2002. Topical Issues of Hungarian Medical Terminology. Debrecen Review. 2.

83. Szabó, Győző. 1996. Papers on the history of justice. Full Court Sessions/National Defense Reviews/"Party" Judgments/Legal Protests/Negotiation Minutes. Budapest.

84. Szabó, Miklós. 1998. Criticism of Istrumental Reason. An Attempt to Characterize the Political Language of the New Hungarian Democracy. Spokesman. 2. Budapest.

85. Szabó, Szilárd. 2019. Central Military and Civilian Intelligence and Counter Intelligence Organizations of the Austro-Hungarian Monarchy 1850-1918. Debrecen.

86. Szabó, Viktor. 2016. Propaganda of the Hungarian Soviet Republic. Doctoral Thesis. Eger. http.//disszertacio.uni-eger.hu/16/1/Szab\%C3\%B3\%20Viktor_\%20\%C3\%A9rtekez\%C3\%A9s.pdf. Accessed 12 May 2019.

87. Szamuely, Tibor. 1919. Commissioner of the People. Cultural propaganda in the Red Army. Budapest's artistic ornament on May 1st. Torch. 2-3. Budapest.

88. Szántó, Zoltán. 1991. Stratify and/or Structure. Replika. 2-3.

89. Szép, Beáta. 2009. Contributions to the History of the Development of the Hungarian Legal Terminology. Hungarian Linguist. 3. Budapest.

90. Takács, Tibor. 2013. Spies about Spying. Reminiscences of Agents from the Kádár era. Budapest.

91. Takács, Tibor. 2013. What are Agent Reports About? Aspects for the Interpretation of "agent files". Presentation in the Historical Archives; Budapest.

92. Takó, Dalma. 2017. Military Criminal Law of the Soviet Republic. Diskurzus, 1. Budapest.

93. Tasnádi Kovács, József. 1920. Christ and the Jews. The Eternal Struggle of God and Satan. Hajdúböszörmény.

94. Thomas, Gordon. 2008. Inside British Intelligence. Budapest.

95. Tolnai, Vilmos. 1923. Artificial Language, Terminology. Budapest: Hungarian Language.

96. Tomolya, János. 2004. Utilization of Experience and Development of Military Terminology. Military Science. 2.

97. Turbucz, Dávid. 2007. The Nature of the Political System in the First Ten Years of the Horthy era. Our Past. 4. Budapest.

98. Tzara, Tristan. 1992. Dada Manifesto 1918. In. Mr. AA the anti-philosopher. Dadaist Manifests and Selected Poems 1914-1936. Budapest.

99. Vajda, Henrik. 2014. Changes in the Terminology of Hungarian Libraries. Book, library, librarians. 4.

100. Varga, János-Szücs, László-Imre, Magda. 1986. Records of the Revolutionary Governing Council 1919. Budapest.

101. Varga, Krisztián. 2015. Enemy on the Left. Political Police in the Horthy-era. Budapest.

102. Váry, Albert. 1920. Charges of Murder, Robbery, etc. Accused of the Crime József Cserny and his Associates. Budapest.

103. Vörös, Boldizsár 2004. "To Erase the Past Forever”? Historical Figures in Hungarian Social Democratic and Communist Propaganda 1890-1919. Budapest.

104. White Terror in Hungary. Report of the British Trade Union Congress (T. U. C.) and the labour delegation. May 1920. Spokesman, 2003. 9. Budapest. 
105. Wittgenstein, Ludwig. 1957. Notes on Logic - 1913. In: The Journal of Philosophy, Vol. 54, No. 9. [https.//www. jstor. org/stable/2021898 Accessed. 12-01-2020].

106. Wittgenstein, Ludwig. 1965. The Blue and Brown Books. Perennial Modern Thought. Preliminary Studies for the Philosophical Investigations 1933-1934. HarperCollins.

107. Wittgenstein, Ludwig. 2004. Wittgenstein at Work. Method in the Philosophical Investigations. ed. Erich Amarelle and Eugen Fischer Routledge.

108. Zimbardo, Philip. 2017. “You May Have Something That No Superhero Has" -Interview made by Csaba Molnár. Hungarian Nation Weekend Magazine, June 4. Budapest.

109. Zweig, Stefan. 2006. Joseph Fouché. Portrait of a Politician. Budapest.

Publisher's Note Springer Nature remains neutral with regard to jurisdictional claims in published maps and institutional affiliations.

\section{Affiliations}

\section{Bela Revesz ${ }^{1}$}

$\checkmark$ Bela Revesz

reves@polit.u-szeged.hu

1 Szegedi Egyetem Allam- es Jogtudomanyi Kar, Szeged, Hungary 